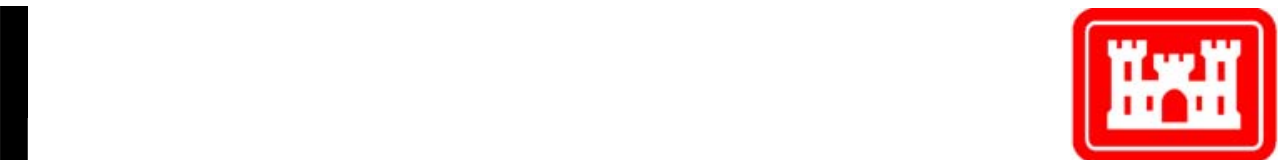

\title{
Wood-Fired Boiler System Evaluation at Fort Stewart, GA
}

Noel L. Potts and Charles M. Schmidt

August 2002
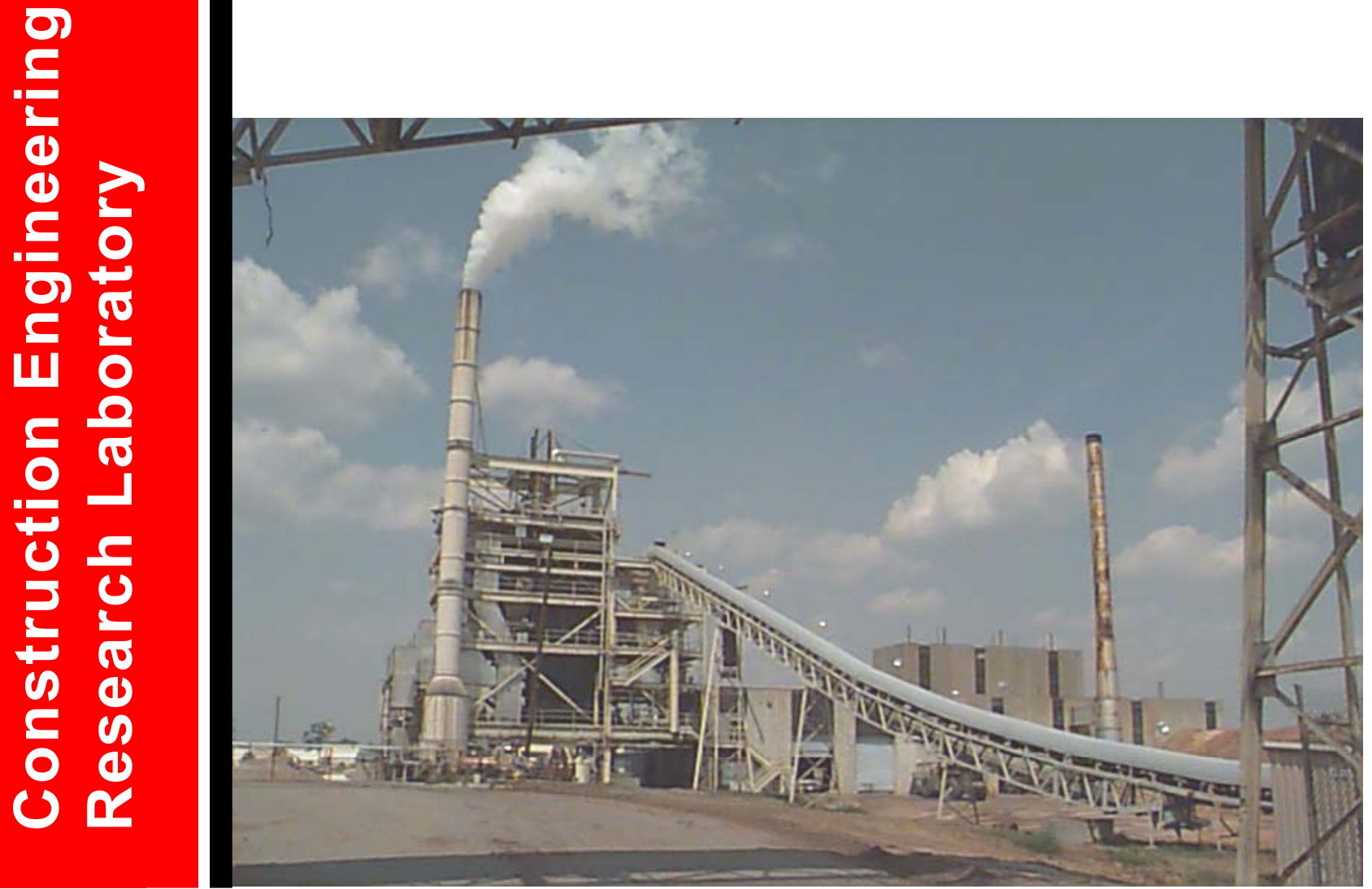


\section{Foreword}

This study was conducted for the Directorate of Public Works, Fort Stewart, GA under Military Interdepartmental Purchase Requests No. OMCER5A190 and OMCER5A191, "Conduct Life Extension Study of Wood Boiler and Equipment for Central Energy Plant Modernization Program." The technical monitor was Fredrick P. Cavedo, Energy Office, Directorate of Public Works, Fort Stewart, GA.

The work was performed by the Energy Branch (CF-E) of the Facilities Division (CF), Construction Engineering Research Laboratory (CERL). The CERL Principal Investigator was Noel L. Potts. Special acknowledgment is given to Charles M. Schmidt and John Salley, Schmidt Associates, Inc., Cleveland, OH, for their efforts in gathering data from the wood-fired boiler at the Fort Stewart Central Energy Plant. The technical editor was William J. Wolfe, Information Technology Laboratory - Champaign. Dr. Thomas Hartranft is Chief, CEERDCF-E, and L. Michael Golish is Chief, CEERD-CF. The Technical Director of the Installation Operations business area is Gary W. Schanche, CEERD-CV-T, and the Director of CERL is Dr. Alan W. Moore.

CERL is an element of the U.S. Army Engineer Research and Development Center (ERDC), U.S. Army Corps of Engineers. The Commander and Executive Director of ERDC is COL John W. Morris III, EN, and the Director of ERDC is Dr. James R. Houston.

DISCLAIMER: The contents of this report are not to be used for advertising, publication, or promotional purposes. Citation of trade names does not constitute an official endorsement or approval of the use of such commercial products. All product names and trademarks cited are the property of their respective owners. The findings of this report are not to be construed as an official Department of the Army position unless so designated by other authorized documents. 


\section{Contents}

Foreword

1 Introduction

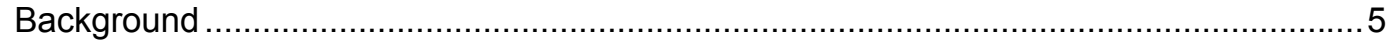

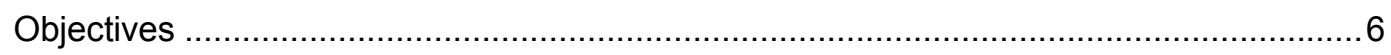

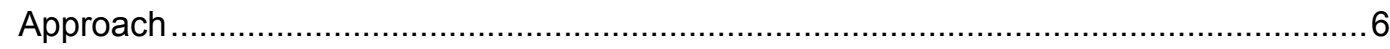

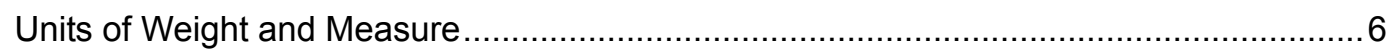

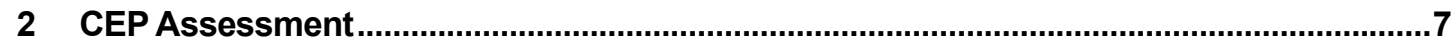

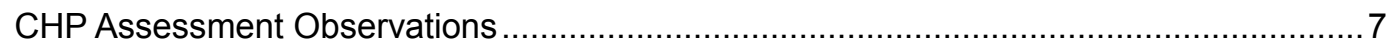

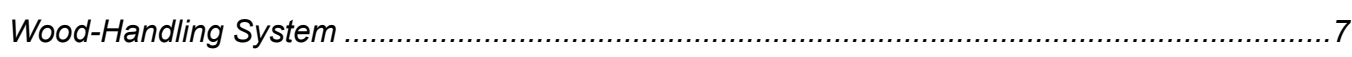

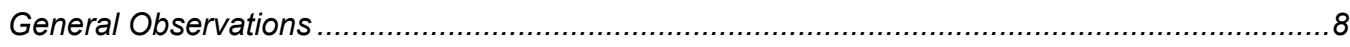

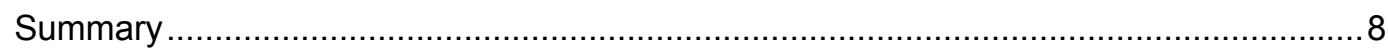

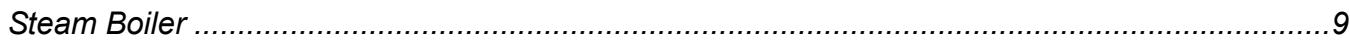

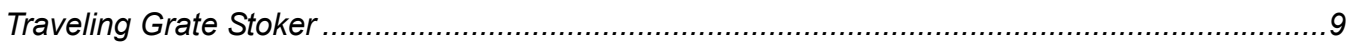

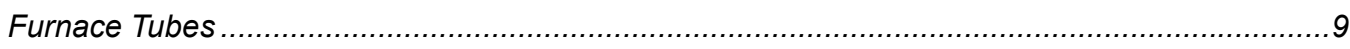

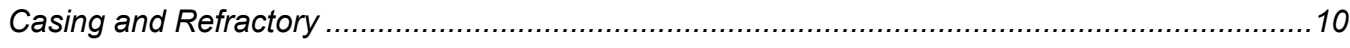

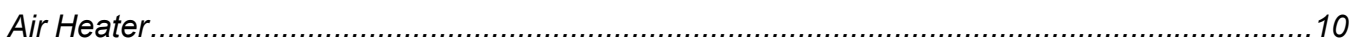

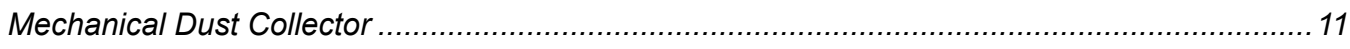

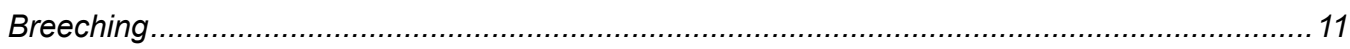

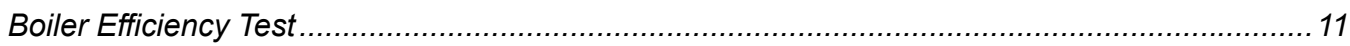

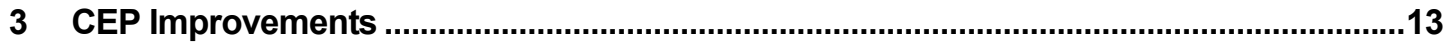

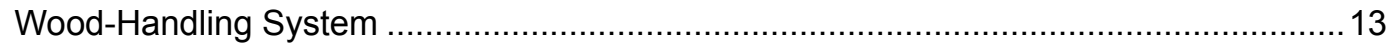

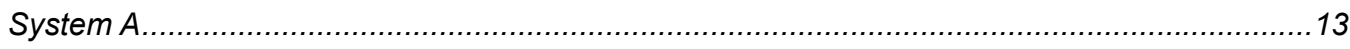

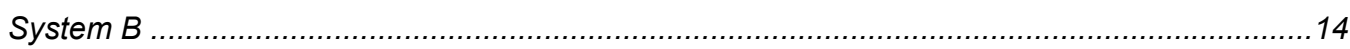

Steam Boiler and Air Heater.............................................................................. 16

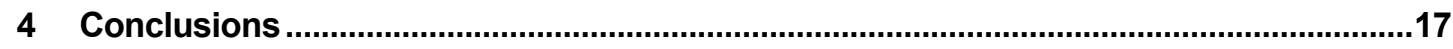

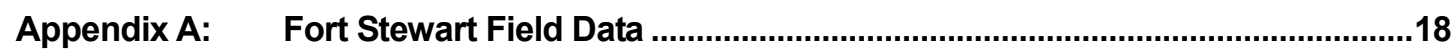

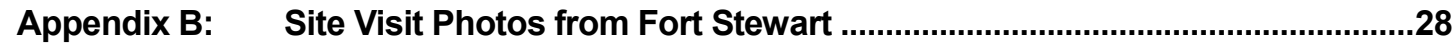

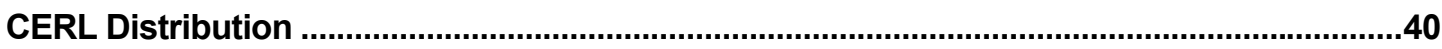

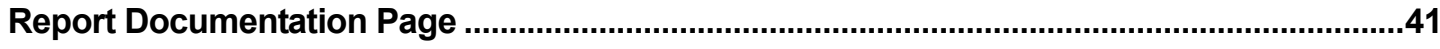




\section{List of Figures and Tables}

\section{Figures}

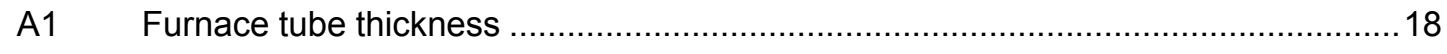

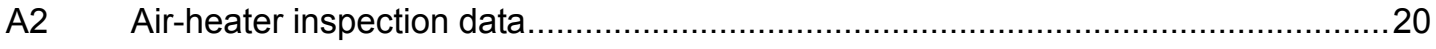

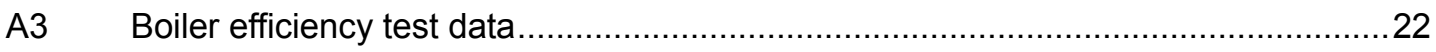

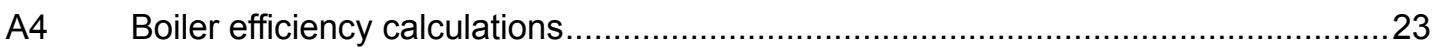

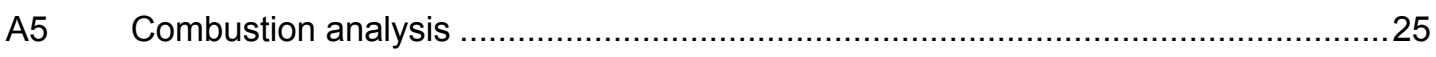

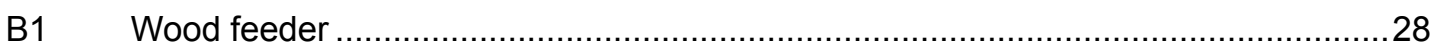

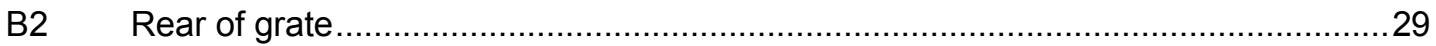

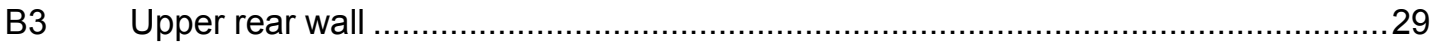

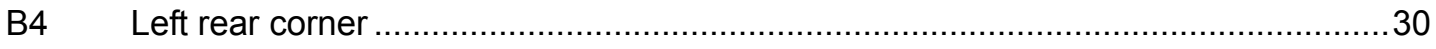

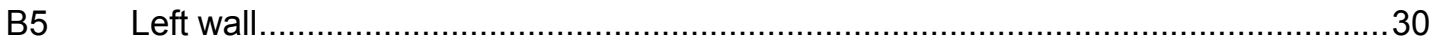

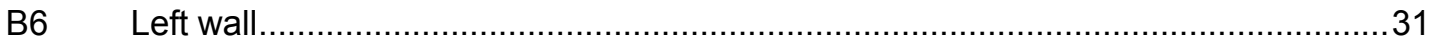

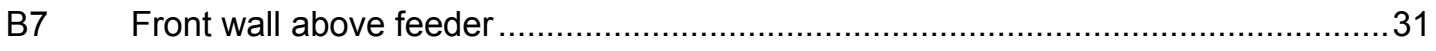

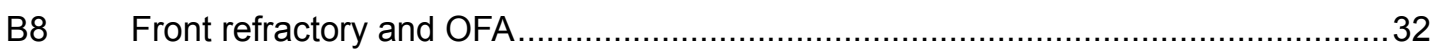

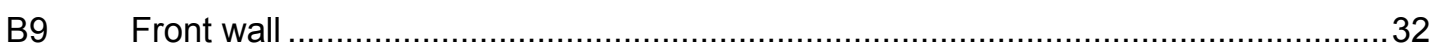

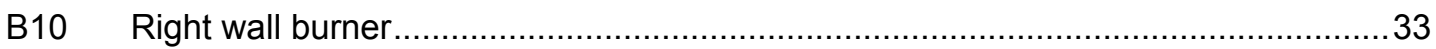

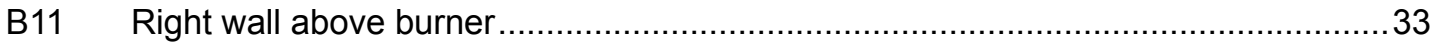

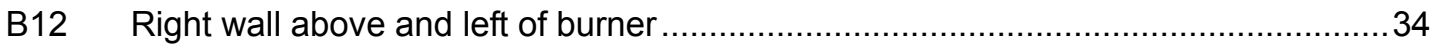

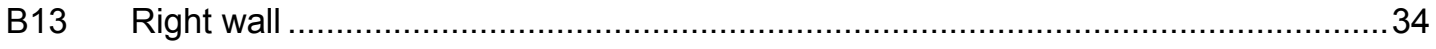

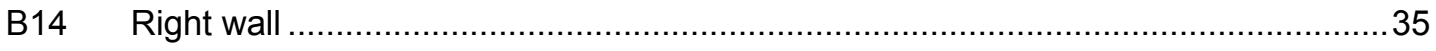

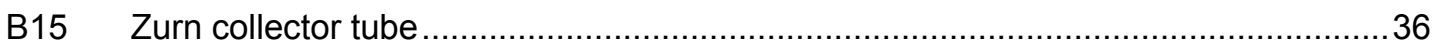

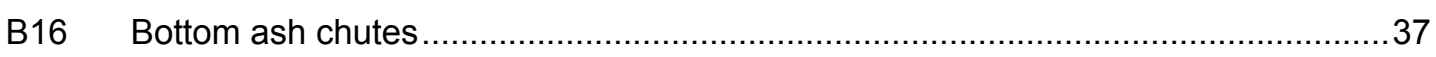

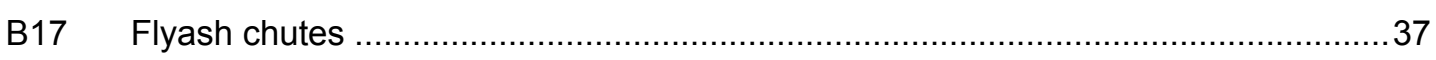

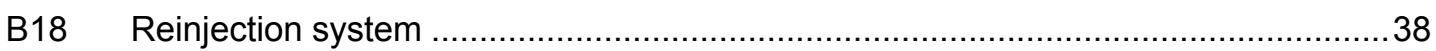

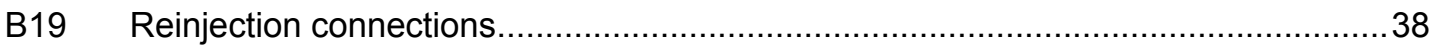

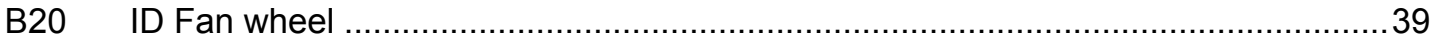

Tables

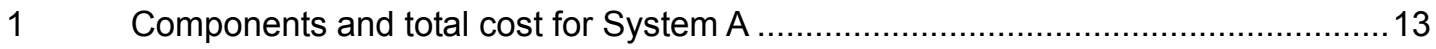

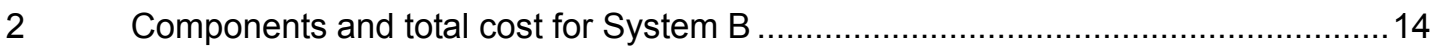

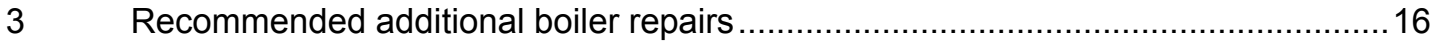




\section{Introduction}

\section{Background}

Part of the plan to modernize the central energy plant (CEP) at Fort Stewart, GA is focused on the installation's wood-fired boiler, which provides steam for heating, cooling, and domestic hot water. The Keeler boiler (E. Keeler Co., Williamsport, PA) is equipped with a Detroit Stoker traveling grate system. Its rated steam output is $94,900 \mathrm{lb} / \mathrm{hr}$. The water tube boiler is operated at $385^{\circ} \mathrm{F}$ at 200 psig. The boiler burns waste wood consisting of a combination of bark, saw dust, and chips. The average moisture content is approximately 45 to 50 percent. Wood fuel is delivered in standard 40-45 ft trailers, which are emptied using a hydraulic truck dump. The wood yard conveyor system (a combination of drag chains and belts) is used to transfer the wood around the yard. An electric magnet is used to remove metal. After metal removal, the wood is delivered to the hammer mill where large pieces are reduced in size. The wood is stored on the ground, uncovered. A front-end loader is used to move the wood around the storage yard and to load the feed bin. Drag chains are used to move the wood to belts that supply the boiler. The wood is emptied into a feed hopper, the level of which is controlled manually.

The steam produced by the wood boiler is connected to a common steam header that is also fed by three natural gas/fuel oil boilers. The steam enters a cascade system to produce high temperature water for the installation. During the cooling season, the steam is also used as the heat source for two absorption chillers with a combined capacity of 2700 tons. Steam production of the boiler is approximately 85,000 lb/hr for 9 months of the year. The CEP burns approximately 55,000 to 65,000 tons of wood per year. The boiler has planned shutdowns twice a year (in April and October) for preventive maintenance and necessary repairs.

The U.S. Army Engineer Research and Development Center, Construction Engineering Research Laboratory (ERDC/CERL) was tasked with supporting Fort Stewart in planning its CEP modernization. Modernization alternatives included repair of leaking hot water distribution systems and partial decentralization of the heating system. 


\section{Objectives}

The objectives of this study were to evaluate the Fort Stewart Wood-Fired Heat Plant equipment and operations to determine the remaining life of the system and to recommend alternatives to extend the system's life for 20 years.

\section{Approach}

1. CERL researchers made site visits 1-3 November 2000 and 5-6 December 2000 to inspect the equipment at the CEP and evaluate its condition.

2. During the visits, CERL and its contractor, Schmidt Associates Inc. (SAI) conducted operational tests, made "cold iron" inspections, and reviewed plant logs.

3. Researchers recorded and analyzed the results of the inspections and tests, and outlined two alternative options, which specify the improvements and repairs needed to extend the system life.

\section{Units of Weight and Measure}

U.S. standard units of measure are used throughout this report. A table of conversion factors for Standard International (SI) units is provided below.

$$
\begin{aligned}
& \text { SI conversion factors } \\
& 1 \mathrm{in} .=2.54 \mathrm{~cm} \\
& 1 \mathrm{ft}=0.305 \mathrm{~m} \\
& 1 \mathrm{lb}=0.453 \mathrm{~kg} \\
& 1 \mathrm{psi}=6.89 \mathrm{kPa} \\
& 1 \mathrm{ton}=907.18 \mathrm{~kg} \\
&{ }^{\circ} \mathrm{F}=\left({ }^{\circ} \mathrm{C} \times 1.8\right)+32
\end{aligned}
$$




\section{CEP Assessment}

During the site visit on 1-3 November 2000, CERL and SAI inspected the furnace, furnace tubes, generation bank, generator outlet duct, mechanical dust collectors, and air heater. Appendix A contains the inspection data.

During the site visit 5-6 December 2000, CERL and SAI conducted a flue gas analysis to determine boiler efficiency and inspected the wood- and ash-handling system.

\section{CHP Assessment Observations}

The following sections summarize condition descriptions recorded during the site visits.

\section{Wood-Handling System}

The wood-handling system was evaluated in operation to determine the modifications that would be required to improve efficiency, reduce equipment wear, and improve safety and reliability.

The wood-handling system currently requires one person to constantly start and stop the system to minimize bridging of wood into the surge hopper directly above the two drag chain fuel feeders to the boiler. The plant personnel constantly monitor the depth of wood in the surge hopper because:

- Too much wood depth results in bridging.

- Too little wood short fuels the boiler.

The condition of the wood-handling system is:

- Scale-The scale is adequate, however the system requires attendance.

- Truck Dumper - The dumper is adequate, however it also requires attendance.

- Receiving Hopper - This unit was not designed to handle wood waste. The knuckle boom was added to deal with bridging. However, the placement of the boom inside the hopper reduces the usable volume of the hopper, which increases the time required to dump a truck, and which requires attendance. 
- Unhogged Conveyor - This unit is adequate. The discharge hood cover and the plugged chute switch needs to be replaced.

- Disc Screen - The disc screen needs to be rebuilt and the discs at the inlet should be spaced closer to prevent spears from passing straight through.

- Wood Hog - This unit is adequate.

- Fixed Stacker - This unit is adequate.

- Reclaim Conveyor - This unit is adequate. The belt scale should be moved and re-calibrated and the discharge hood should be covered. If the small inlet hopper is to remain, the skirting should be continuous back to the original load hopper. A magnetic separator should be added to this conveyor.

- Reclaim Hopper - This unit is too narrow. The narrow width causes the hopper to bridge frequently and prevents the unit from holding a sufficient surge volume. This unit should be replaced.

- Transfer Conveyor from Reclaim Hopper - This unit is too high above the ground, and is too short for the new underpile reclaimer arrangement. This unit should be replaced.

- Metering Bin - The unit operates fairly well, but requires continuous monitoring to ensure that the unit is not bridging. The operator empties the bin every cycle. This allows tramp air to enter the boiler and provides no surge capacity if a problem should occur when the bin is near empty. The chain conveyors have an open area at the back to allow the return chains to clean out. There are also large openings at the screw take-up. Both openings allow tramp air to enter the boiler. Additionally, the covers and poke holes have many areas that should be sealed up.

\section{General Observations}

- All belt cleaners should be serviced and adjusted.

- All speed switches should be tested and/or replaced.

- Some return idlers show excessive wear and should be replaced.

- This study did not check the condition of the belts.

- The Fuel Yard should be paved.

\section{Summary}

The existing system is very manpower dependent. It requires extensive use of mobile equipment, and cannot supply the boiler with consistent fuel on a continuous basis for a prolonged period of time. The system does not provide an adequate air seal at the boiler. 


\section{Steam Boiler}

\section{Traveling grate stoker}

Some damage to the front area of the boiler and grate from excessive temperatures is apparent (Figure B1) ${ }^{*}$. The rear tubes are burnt and need replacing (Figure B2). The damaged areas of the boiler are the insulating trays and the guide supports on the grate. The damage appears to be caused by air entering the boiler through the ash removal system.

The original water seal and drag chain has been removed and replaced with an open duct with a metal door that dumps directly onto the ground. A slide gate above the door has been damaged by excessive heat and is not used. The operating procedure is to open the metal door if there is piling in the front of the grate to burn it off. The grate temperature thermocouples were not connected. (Most wiring and junctions are missing.) The rails and all supporting steel look good. The grate bars and chains are also good. The air seals were replaced around May 2000 and look good. The bark chutes have been repaired and patched several times, but appear operational. Plant personnel should check the rotary air dampers and minimum flow dampers for stability and proper operation when the boiler is operational. A pressure gauge should be installed on each damper to check minimum and maximum flows and adjusted on-line.

\section{Furnace tubes}

The furnace has 122 tubes, specified to have an outside diameter of $3.25 \mathrm{in}$. and a wall thickness of $0.165 \mathrm{in}$. There are 39 tubes on each of the left and right walls and 22 tubes on each of the front and rear walls. Ultrasonic thickness testing was conducted on 18 of the left wall tubes and 18 of the right wall tubes at both 6 and $12 \mathrm{ft}$ above the grate. Testing was conducted on 11 of the front wall tubes at $7 \mathrm{ft}$ above the grate and on 11 of the rear wall tubes at both 6 and $12 \mathrm{ft}$ above the grate. Figure A1 (in Appendix A to this report) contain these test results. The left wall tubes had a minimum thickness of 0.166 in. and a maximum thickness of $0.171 \mathrm{in}$., the right wall tubes had a minimum thickness of $0.168 \mathrm{in}$. and a maximum thickness of $0.172 \mathrm{in}$. The front wall tubes had a thickness of 0.169 to $0.173 \mathrm{in}$. and the rear wall tubes had a thickness of 0.170 to $0.174 \mathrm{in}$.

\footnotetext{
*All photographic figures are included in Appendix B to this document.
} 
All of the tubes tested are within manufacturing tolerances and appear to be new. Based upon the ASME code for tubes designated as SA-178 Grade A, the allowable working pressure is over 1000 psig.

\section{Casing and refractory}

While tube thickness does not appear to be a problem, tube alignment and refractory condition are major problems (Figures B3 to B14). The left and right wall tubes are both bowed approximately 1 to $2 \mathrm{in}$. towards the middle of the furnace. The bowing starts about $3 \mathrm{ft}$ above the grate and extends up to the top of the bridgewall. The tube misalignment is caused by the condition of the refractory. There are numerous places where the refractory behind the furnace tubes has cracked, moved, and/or fallen out. It is very likely that the tube ties have broken due to deterioration of the refractory, which has allowed the tube ties to be exposed to radiant heat in the furnace. The refractory has fallen out with the opening almost to the outside casing in several places.

\section{Air heater}

The air heater, located between the boiler outlet and mechanical collector inlet is used to preheat the combustion air and increase boiler efficiency. The air heater is a tubular type, in which the hot flue gas travels through the inside of the tube and transfers heat to the combustion air moving around the outside of the tubes. Because the flue gas side of the air heater is under negative pressure and the combustion air side is under positive pressure, any holes in the tubes or the sheets will allow combustion air to travel into the flue gas stream. The air infiltration will decrease the flue gas temperature and increase the flue gas oxygen content. The cooler flue gas increases the chance of acid condensation at lower boiler loads, which causes corrosion of the air heater tubes and scale buildup as the load is increased and the acids evaporated.

The air heater (diagrammed in Figure A2) contains a total of 999 tubes, arranged with 54 rows of tubes across the width of the boiler (from left to right) and 19 tubes per row in the odd numbered rows and 18 tubes per row in the even numbered rows. Tube corrosion is a problem as evidenced by the condition of the tubes. Ninety-nine of the tubes have been mechanically plugged due to holes in the tubes. Another four tubes at the inlet end and twelve at the outlet end are plugged with flyash. There are also three tubes that were found to have holes in them. Leakage in the air heater was confirmed during the on-line boiler evaluation. At the boiler outlet the flue gas oxygen content was measured to average 11.1 percent by volume on a dry basis. At the air heater outlet the flue gas oxygen content had increased to 13.3 percent on a dry volume basis. This was at a 
boiler load of 70,000 to 78,000 lb/hr. At lower boiler loads, the oxygen will be even higher. High oxygen levels will cause the carbon in the flyash to begin to glow and eventually burn causing warpage of metal. The hoppers of the mechanical dust collector were replaced due to fires and warpage of the walls. All of the tubes should be replaced.

\section{Mechanical dust collector}

The mechanical dust collector is a multi-clone type manufactured by Zurn Industries (Figure B15). The unit has a total of 40 tubes arranged 8 rows across the width of the boiler and 5 rows deep. The ash is collected in two hoppers.

The inlet guide vanes are in excellent condition with no scale buildup or broken vanes. The collecting tubes are also in excellent condition with no signs of flyash erosion patterns or holes. The gaskets between the bottom tube sheet and the collecting tube are in good condition with no evidence of leakage. The dust discharge boots at the bottom of the collecting tubes are tight to the tubes but are warped, probably due to fires in the hoppers. These boots should be replaced to ensure optimal collection efficiency. The hoppers have been recently replaced and do not exhibit any signs of leakage. The only other problem found was on the right section of the clean gas tube sheet where there was a $3 / 4-i n$. hole in the sheet allowing some of the dirty flue gas to bypass the mechanical collector. This hole should be patched.

\section{Breeching}

The only area of the breeching that was found to be in need of repair was at the boiler outlet. The vertical refractory on the right side of the boiler between the boiler outlet and the air heater transition piece had a 2 -in. wide opening that exposed the blanket insulation.

\section{Boiler efficiency test}

During the evaluation site visit 05-06 Dec 2000, a boiler efficiency test was conducted to determine the current operation of the boiler. The test was conducted at a boiler steam flow of 68,000 to $78,000 \mathrm{lb} / \mathrm{hr}$ or 72 to 82 percent of capacity. The flue gas was sampled at the boiler outlet and air heater outlet using an Enerac $2000 \mathrm{E}$ for flue gas analysis and thermocouples for flue gas temperature. Figure A3 shows the test results.

The flue gas at the boiler outlet averaged 11.1 percent $\mathrm{O}_{2}$ on a dry volume basis, which compares very well with the plant oxygen analyzer of 9.6 percent $\mathrm{O}_{2}$ on a 
wet volume basis. The flue gas temperature using the portable thermocouple was $493^{\circ} \mathrm{F}$ versus the plant temperature of $478^{\circ} \mathrm{F}$. The $\mathrm{CO}$ averaged $1868 \mathrm{ppm}$ and $\mathrm{NOx}$ averaged $73 \mathrm{ppm}$, both on an uncorrected oxygen basis.

The flue gas at the air heater outlet averaged 13.3 percent $\mathrm{O}_{2}$ on a dry volume basis with $672 \mathrm{ppm}$ of $\mathrm{CO}$ and $55 \mathrm{ppm}$ of NOx. The flue gas temperature was $346^{\circ} \mathrm{F}$.

The boiler efficiency was calculated according to the American Society of Mechanical Engineers (ASME), Power Test Code PTC 4.1, "Abbreviated Efficiency Test, Heat Loss Method." Using the boiler outlet flue gas oxygen of 11.1 percent and the air heater outlet flue gas temperature of $346^{\circ} \mathrm{F}$, the efficiency was calculated to be 64.57 percent. This efficiency includes a carbon loss (unburned carbon) of 2.00 percent and a radiation loss (heat loss through the boiler casing) of 0.71 percent.

The boiler outlet oxygen content of 11.1 percent dry volume or 9.6 percent wet volume means the boiler is operating at over 110 percent excess air. This is much too high for efficient operation. Typical operation should normally be around 50 percent excess air. The excess oxygen is most likely entering the furnace through the misaligned or missing refractory previously mentioned. By reducing the excess air from 110 to 50 percent, the boiler efficiency will increase by 2.6 percent which will reduce the fuel input by the same amount.

The flue gas oxygen content increased from 11.1 percent at the boiler outlet to 13.3 percent at the air heater outlet. This is due to the poor condition of the air heater tubes, which allows some of the forced draft combustion air to mix with the flue gas. This increases the mass flue gas flow by 25 percent.

By increasing the excess air from 50 to 110 percent, the mass flue gas flow will increase by 34 percent. This will cause higher flue gas velocities through the generation section of the boiler resulting in reduced heat transfer from the flue gas to the water in the tubes and increase tube erosion by the flyash. 


\section{CEP Improvements}

The results of the site investigation indicate several areas where design, repair, and maintenance improvements are needed to modernize the CEP for continued operation for the next 20 years.

\section{Wood-Handling System}

The two options for improvement of the wood-handling system described in the following sections have different manpower and implementation costs.

\section{System A}

Table 1 lists the components and total cost for System A.

Table 1. Components and total cost for System A.

\begin{tabular}{|c|c|c|}
\hline No. & Component & Total Cost \\
\hline 1 & $\begin{array}{l}8 \mathrm{ft}, 0 \text { in. wide } \times 33 \mathrm{ft}, 0 \text { in. centers, } 4 \text {-chain underpile reclaimer with } 2 \text {-spike roll } \\
\text { discharger. The unit shall be powered by a } 15 \mathrm{HP} \text { variable speed drive and the } \\
\text { spike rolls shall be powered by a } 10 \mathrm{HP} \text { drive. }\end{array}$ & \\
\hline 1 & $\begin{array}{l}36 \text { in. wide x } 57 \mathrm{ft}, 0 \text { in. } \pm \text { long, } 35 \text { degree troughed, collection conveyor with chan- } \\
\text { nel frame, belt scale and } 10 \mathrm{HP} \text { drive. }\end{array}$ & \\
\hline 1 & $\begin{array}{l}36 \text { in. wide } x 78 \mathrm{ft}, 0 \text { in. } \pm \text { long, } 35 \text { degree troughed, transfer conveyor with channel } \\
\text { frame and } 10 \mathrm{HP} \text { drive. }\end{array}$ & \\
\hline 1 & Electromagnet with support structure and mono-rail. & \\
\hline 1 & Relocate and recalibrate existing scale on the existing reclaim conveyor. & \\
\hline 1 & Extend the existing reclaim conveyor to the center of the boiler. & \\
\hline 1 & $\begin{array}{l}\text { Double discharge, six screw, live bottom metering bin, mounted on load cells and } \\
\text { complete with high/high level indication. The unit shall be powered by two } 15 \text { HP } \\
\text { VFD drives which shall be controlled by the existing boiler controller. }\end{array}$ & \\
\hline 2 & Chutes with thermal expansion joints to the existing solid fuel stoker chutes. & \\
\hline 1 & $\begin{array}{l}\text { Lot existing conveyor belt cleaners, and zero speed switches, repair/replacement } \\
\text { and adjustment. }\end{array}$ & \\
\hline 1 & Rebuild of existing disc screen (primarily new rotors). & \\
\hline 1 & $\begin{array}{l}\text { Discharge hood cover and plugged chute switch for the existing unhogged belt } \\
\text { conveyor. }\end{array}$ & \\
\hline \multirow[t]{2}{*}{1} & Lot civil, mechanical and electrical construction of the above described equipment. & \\
\hline & $\begin{array}{l}\text { Total Estimated Budget Price for Wood-Handling System A Equipment/Construction } \\
\text { as Described }\end{array}$ & $\$ 1,328,000$ \\
\hline
\end{tabular}


System A will provide fuel continuously to the boiler for a prolonged period of time and will provide an adequate air seal at the boiler. The system will not significantly reduce manpower. However, it will reduce the demands on the operating personnel. The new reclaim hopper can be heaped and left unattended for an hour. This metering bin will operate automatically, requiring attention only if there is a malfunction. The magnetic separator will keep tramp metal out of the metering bin and out of the ash stream. Keeping tramp iron out of the ash becomes even more important if the ash system is automated.

Paving the fuel yard helps prevent dirt and rocks from entering the fuel supply, shortens mobile equipment cycle time, reduces wear on mobile equipment, is less prone to cause personal back injuries, and reduces fugitive dust problems.

\section{System B}

Table 2 lists the components and total cost for System B.

Table 2. Components and total cost for System B.

\begin{tabular}{|c|c|c|}
\hline No. & Component & Total Cost \\
\hline 1 & $\begin{array}{l}\text { Six chain, } 4,800 \text { cu ft truck receiving hopper with single spike roll discharger } \\
\text { and adjustable strike-off gate. The unit shall be powered by a } 60 \mathrm{HP} \text { variable } \\
\text { speed drive and a } 7-1 / 2 \mathrm{HP} \text { spike roll drive. }\end{array}$ & \\
\hline 1 & $\begin{array}{l}\text { Lot automation of the truck scale/dumper to allow truck drivers to dump their } \\
\text { own trucks and to automatically print tickets. }\end{array}$ & \\
\hline 1 & $\begin{array}{l}\text { Discharge hood cover and plugged chute switch for existing unhogged belt } \\
\text { conveyor. }\end{array}$ & \\
\hline 1 & Rebuild of existing disc screen (primarily new rotors). & \\
\hline 1 & $\begin{array}{l}\text { 48-in. wide } \times 144 \mathrm{ft}, 0 \text { in. } \pm \text { long, } 35 \text { degree troughed, inclined stacker feed } \\
\text { conveyor with truss, frame and walkway. The unit shall be powered by a } 20 \mathrm{HP} \\
\text { drive. }\end{array}$ & \\
\hline 1 & $\begin{array}{l}\text { 1,300 ton capacity, twin pile, stacker reclaimer with independent PLC controls. } \\
\text { The unit shall be capable of automatically stacking wood waste }(20 \mathrm{lb} / \mathrm{cu} \mathrm{ft}) \text { at } \\
\text { the rate of } 75 \text { tons per hour, designed to provide complete reclaiming to grade } \\
\text { automatically, at the rate of } 4 \text { to } 24 \text { tons per hour. The unit shall not require } \\
\text { underground pits and shall be capable of stacking and reclaiming simultane- } \\
\text { ously without attendance, in winds up to } 45 \text { miles per hour. The reclaimer shall } \\
\text { be powered by } 71 / 2 \mathrm{HP}, 40 \mathrm{HP} \text {, and } 30 \mathrm{HP} \text { motors and the stacker shall be pow- } \\
\text { ered by a } 10 \mathrm{HP} \text { motor. }\end{array}$ & \\
\hline 1 & $\begin{array}{l}30 \text { in. wide } \times 60 \mathrm{ft}, 0 \text { in. } \pm \text { long, } 35 \text { degree troughed, stacker/reclaimer collec- } \\
\text { tion conveyor with channel frame, belt scale and } 10 \mathrm{HP} \text { drive. }\end{array}$ & \\
\hline 1 & $\begin{array}{l}8 \mathrm{ft}, 0 \text { in. wide } \times 33 \mathrm{ft}, 0 \text { in. centers, } 4 \text {-chain underpile reclaimer with } 2 \text {-spike roll } \\
\text { discharger. The unit shall be powered by a } 15 \mathrm{HP} \text { variable speed drive and the } \\
\text { spike rolls shall be powered by a } 10 \mathrm{HP} \text { drive. }\end{array}$ & \\
\hline 1 & $\begin{array}{l}36 \text { in. wide } x 51 \mathrm{ft}, 0 \text { in. } \pm \text { long, } 35 \text { degree troughed underpile reclaimer collec- } \\
\text { tion conveyor with channel frame, belt scale and } 10 \mathrm{HP} \text { drive. }\end{array}$ & \\
\hline 1 & $\begin{array}{l}36 \text { in. wide } \times 78 \mathrm{ft}, 0 \text { in. } \pm \text { long, inclined transfer conveyor with channel frame } \\
\text { and } 10 \mathrm{HP} \text { drive. }\end{array}$ & \\
\hline
\end{tabular}




\begin{tabular}{|c|c|c|}
\hline No. & Component & Total Cost \\
\hline 1 & Electromagnet with support structure and monorail. & \\
\hline 1 & Relocate and recalibrate existing scale on the existing reclaim conveyor. & \\
\hline 1 & Extend the existing reclaim conveyor to the center of the boiler. & \\
\hline 1 & $\begin{array}{l}\text { Double discharge, six screw, live bottom metering bin, mounted on load cells } \\
\text { and complete with high/high level indication. The unit shall be powered by two } \\
15 \text { HP VFD drives which shall be controlled by the existing boiler controller. }\end{array}$ & \\
\hline 2 & Chutes with thermal expansion joints to the existing solid fuel stoker chutes. & \\
\hline 1 & $\begin{array}{l}\text { Lot existing conveyor belt cleaners and zero speed switches, re- } \\
\text { pair/replacement and adjustment. }\end{array}$ & \\
\hline 1 & $\begin{array}{l}\text { PLC with operating program for the entire fuel handling system, capable of } \\
\text { interfacing with the existing boiler control system. }\end{array}$ & \\
\hline \multirow[t]{2}{*}{1} & $\begin{array}{l}\text { Lot civil, mechanical and electrical construction of the above described equip- } \\
\text { ment. }\end{array}$ & \\
\hline & $\begin{array}{l}\text { Total Estimated Budget Price For Wood-Handling System B Equip- } \\
\text { ment/Construction as Described }\end{array}$ & $\$ 4,525,000$ \\
\hline
\end{tabular}

System B will also provide fuel continuously to the boiler for a prolonged period of time and will provide an adequate air seal at the boiler. Additionally, this system will allow manpower to be reduced. The minimum operating personnel could be as few as two on the first shift and one on each of the night shifts. This will in turn reduce the number of front-end loaders required.

The system will automatically blend the fuel when it is sent to the stacker reclaimer and allows the fuel from long-term storage to be blended through the underpile reclaimer. The truck dump/weighing system would be automated allowing the truck drivers to dump their own trucks. The only operator intervention required is to select the destination for the fuel. The only fuel that will be handled by front-end loader is the fuel to and from long-term storage. Fuel in long-term storage can be sent to the boiler through the underpile reclaimer or through a man-made pile at the stacker reclaimer. The new underpile reclaimer can be heaped and left unattended for an hour. The stacker/reclaimer can be loaded by front-end loader or automatically and may be left unattended for 3 to 4 days.

The metering bin will operate automatically, requiring attention only if there is a malfunction. The magnetic separator will keep tramp metal out of the metering bin and out of the ash stream. Keeping tramp iron out of the ash becomes even more important if the ash system is automated.

Paving the fuel yard will help prevent dirt and rocks from entering the fuel supply, increase mobile equipment cycle time, reduce wear on mobile equipment, reduce fugitive dust problems, and be less prone to cause personal back injuries. 


\section{Steam Boiler and Air Heater}

The steam boiler and air heater require major repairs to extend the operating life another 20 years. The furnace section of the boiler will require complete removal of the outside casing for complete replacement of the existing firebrick tile, high-temp block insulation, blanket insulation, and tube ties. The standard square edge tile should be replaced with shiplap design tile in an attempt to eliminate the tile movement condition that now exists. Table 3 lists recommended additional boiler and air heater repairs. The total estimated budget price for steam boiler and air heater equipment/construction as described in this paragraph (and Table 3) is $\$ 917,000$.

Table 3. Recommended additional boiler repairs.

\begin{tabular}{|l|}
\hline Component \\
\hline Complete replacement of the first pass baffle tile and corner seals \\
\hline Complete replacement of the lower front wall castable insulation and anchors \\
\hline Complete replacement of the front ash hopper castable insulation and anchors \\
\hline Complete replacement of the drum end insulation and aluminum lagging \\
\hline The air heater requires complete replacement of all 999 tubes \\
\hline
\end{tabular}




\section{Conclusions}

This study evaluated the Fort Stewart Wood-Fired Heat Plant equipment and operations to determine the remaining life and alternatives for extending the system's life for 20 years.

The evaluation showed that the existing system is very manpower dependent. The system requires extensive use of mobile equipment and yet cannot supply the boiler with consistent fuel on a continuous basis for a prolonged period of time. The system also does not provide an adequate air seal at the boiler (Chapter 2).

Design, repair, and maintenance changes are needed in several areas to modernize the CEP for continued operation for the next 20 years, including two available options for improving the wood-handling system (pp 7, 14) and major repairs to the steam boiler and air heater system (p 16). 


\section{Appendix A: Fort Stewart Field Data}

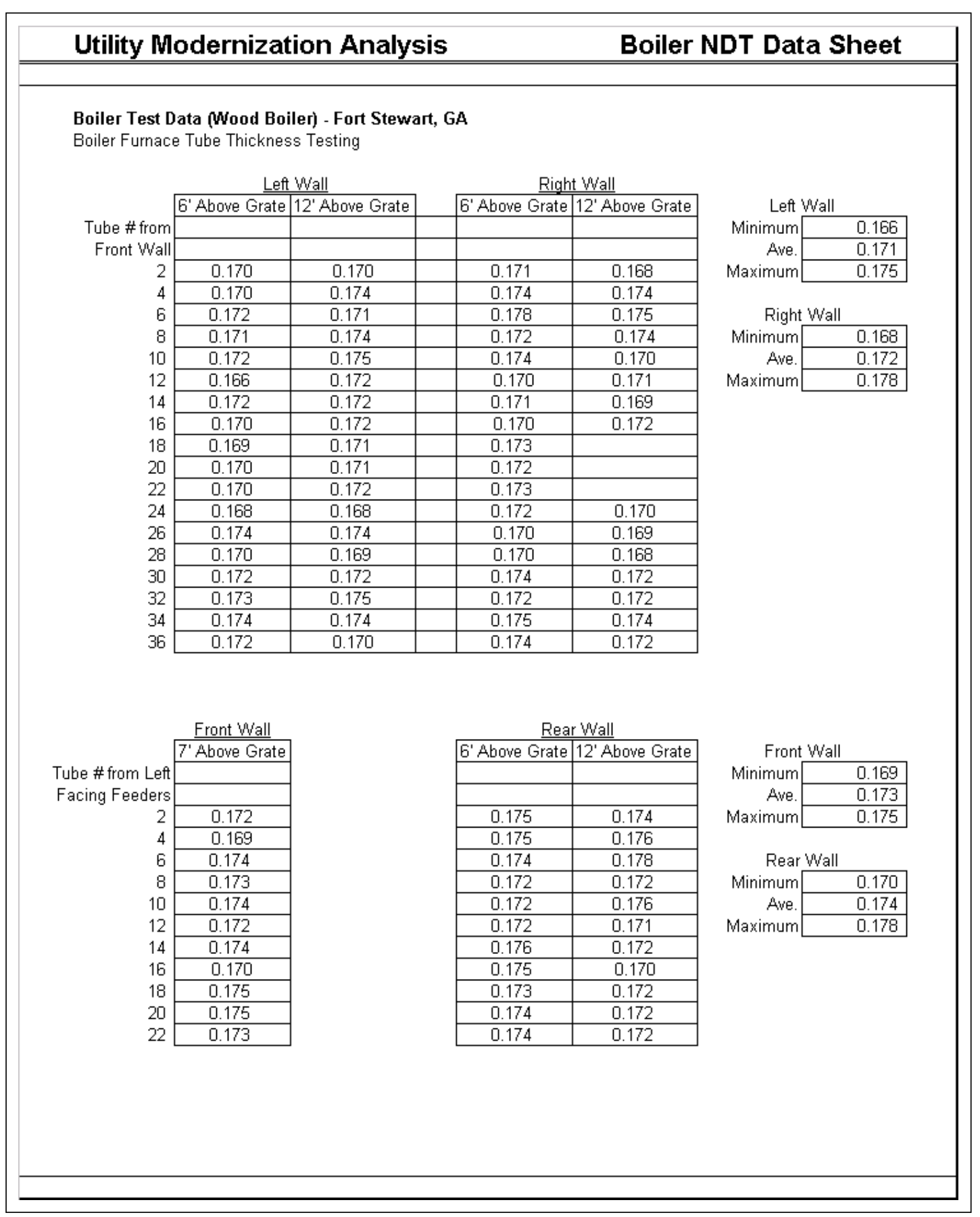

Figure A1. Furnace tube thickness. 


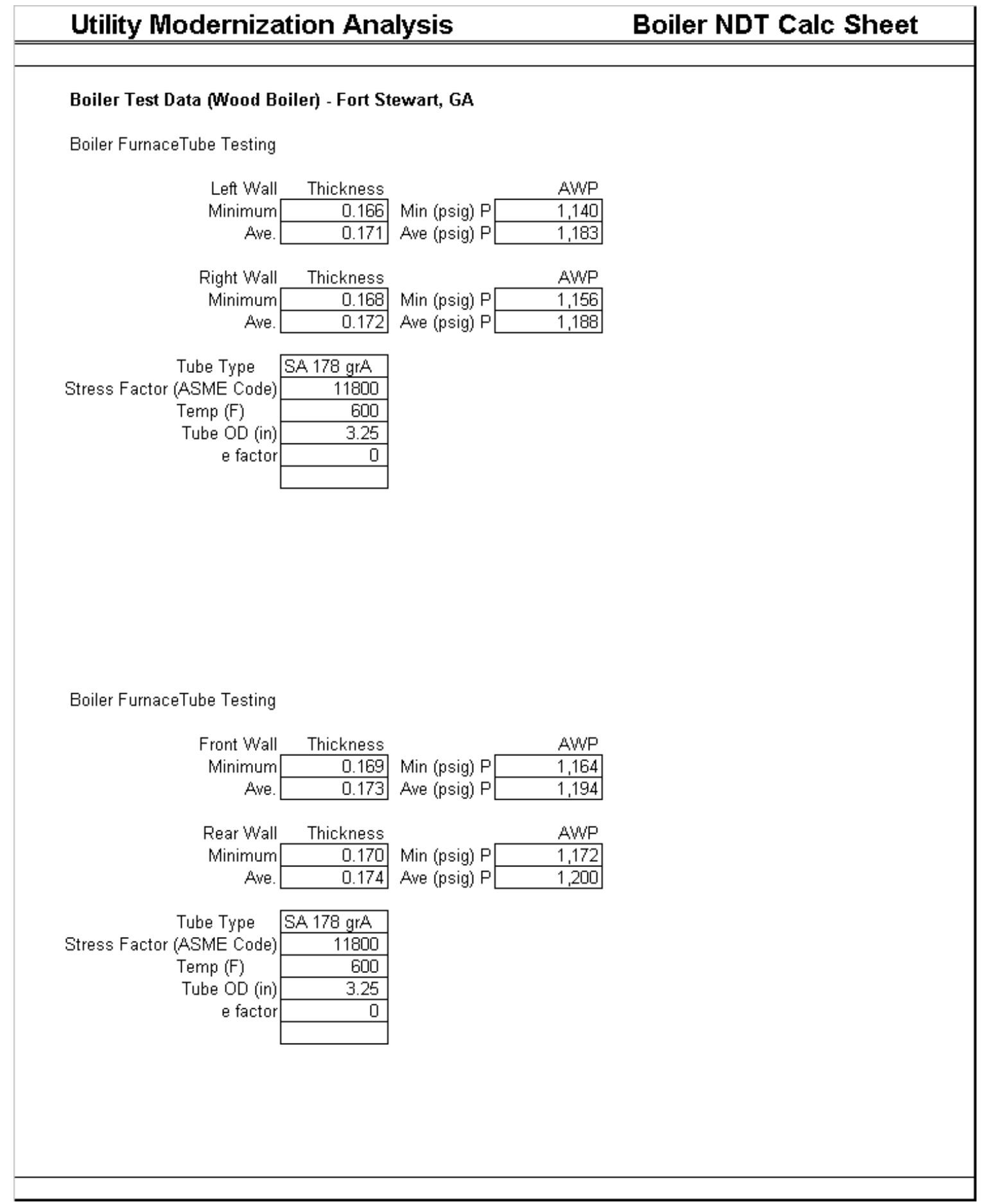

Figure A1. (cont'd). 


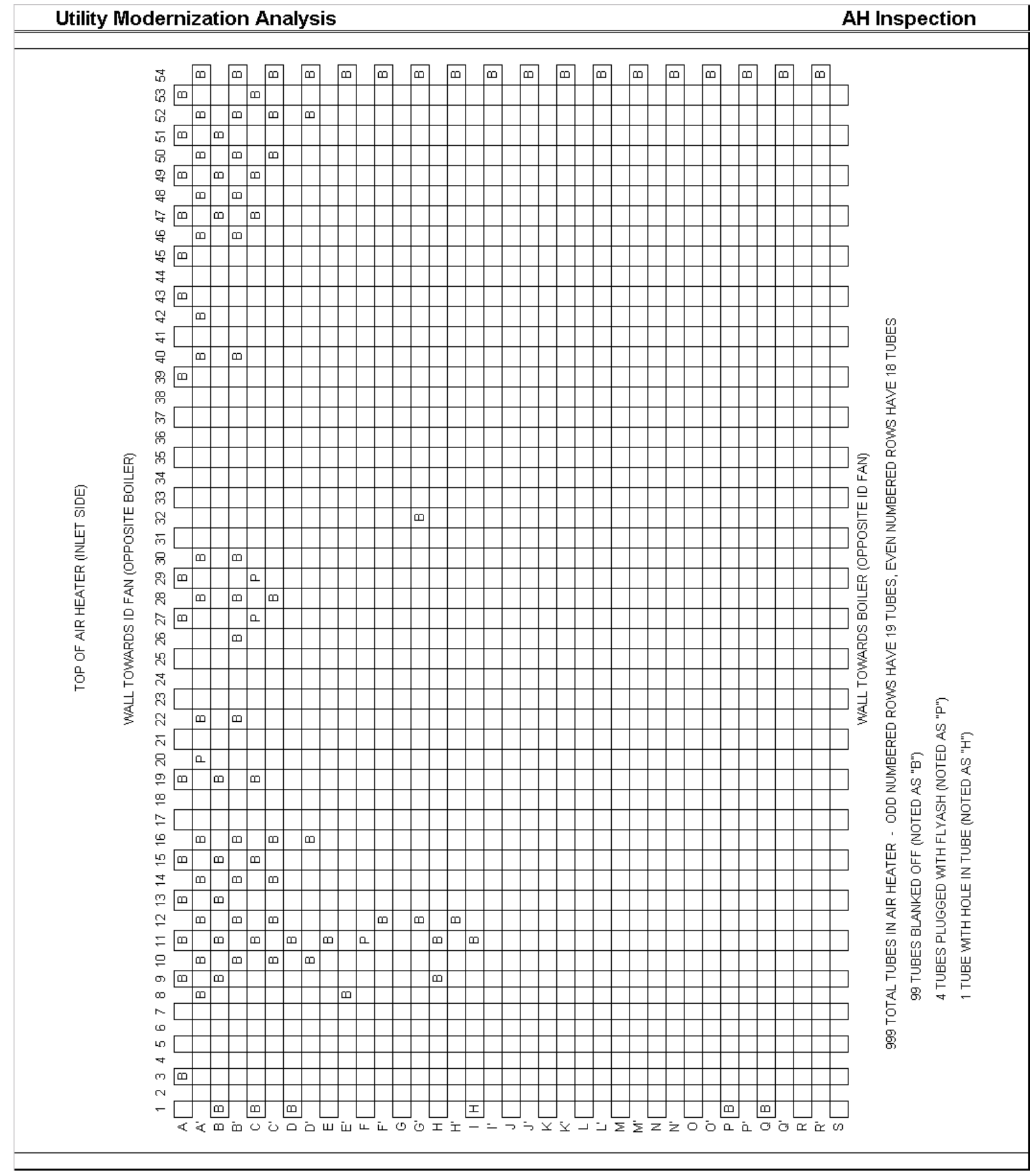

Figure A2. Air-heater inspection data. 


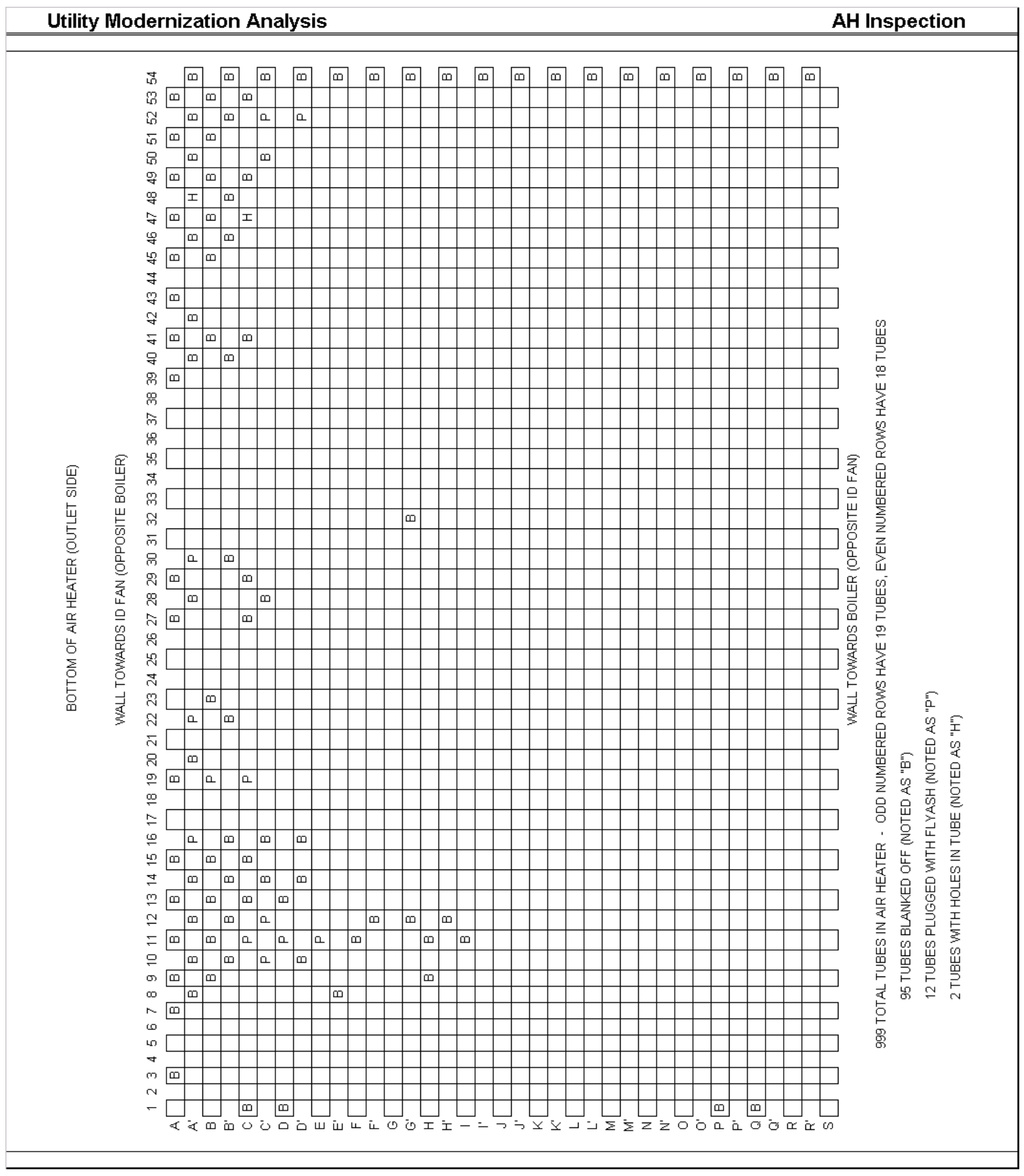

Figure A2. (Cont'd). 
Utility Modernization Analysis Boiler Data Sheet

Boiler Test Data (Wood Boiler) - FT. STEWART, GA 05 Dec 2000

Plant/Gage Readings

\begin{tabular}{r|r|r|r|r|r|r|}
\cline { 2 - 7 } Time & $15: 47$ & $16: 04$ & $16: 05$ & $16: 08$ & $16: 11$ & $16: 12$ \\
\cline { 2 - 7 } Flue Gas Temp (F) & & 514 & 514 & 514 & & 478 \\
\cline { 2 - 7 } Oxygen $\%$ & 9.1 & 9.9 & 11.3 & 9.4 & 8.1 & 9.5 \\
\cline { 3 - 7 } Steam Flow (Klbs/hr) & 70 & 70 & 70 & 70 & 70 & 68 \\
\hline
\end{tabular}

Boiler Outlet Data (Enerac)

\begin{tabular}{|c|c|c|c|c|c|c|}
\hline \multirow{2}{*}{$\begin{array}{r}\text { Oxygen } \% \\
\text { Combustibles } \%\end{array}$} & 10.9 & 11.2 & 12.7 & 11.0 & 10.4 & 10.2 \\
\hline & 0.31 & 0.34 & 0.40 & 0.31 & 0.36 & 0.35 \\
\hline $\mathrm{CO}(\mathrm{ppm})$ & 1248 & 1598 & 2200 & 1952 & 2200 & 2008 \\
\hline NO $(\mathrm{pm})$ & 51 & 69 & 68 & 66 & 59 & 58 \\
\hline NO2 $(\mathrm{ppm})$ & 0 & 12 & 13 & 15 & 15 & 16 \\
\hline NOX $(\mathrm{ppm})$ & 51 & 80 & 80 & 81 & 73 & 73 \\
\hline $\mathrm{SO}(\mathrm{ppm})$ & 0 & 0 & 0 & 0 & 0 & 0 \\
\hline as Temperature (F) & & & & & & 493 \\
\hline Ambient Temperature $(\mathrm{F})$ & 93 & 87 & 86 & 83 & 82 & 82 \\
\hline
\end{tabular}

Plant/Gage Readings

\begin{tabular}{|c|c|c|c|c|c|}
\hline \multirow{2}{*}{$\begin{array}{r}\text { Time } \\
\text { Flue Gas Temp (F) }\end{array}$} & $16: 47$ & $16: 49$ & $16: 58$ & $17: 03$ & 17:03 \\
\hline & & & & & \\
\hline Oxygen $\%$ & 9.0 & & & & \\
\hline Steam Flow (Klbs/hr) & 78 & & & & \\
\hline
\end{tabular}

Air Heater Outlet Data (Enerac)

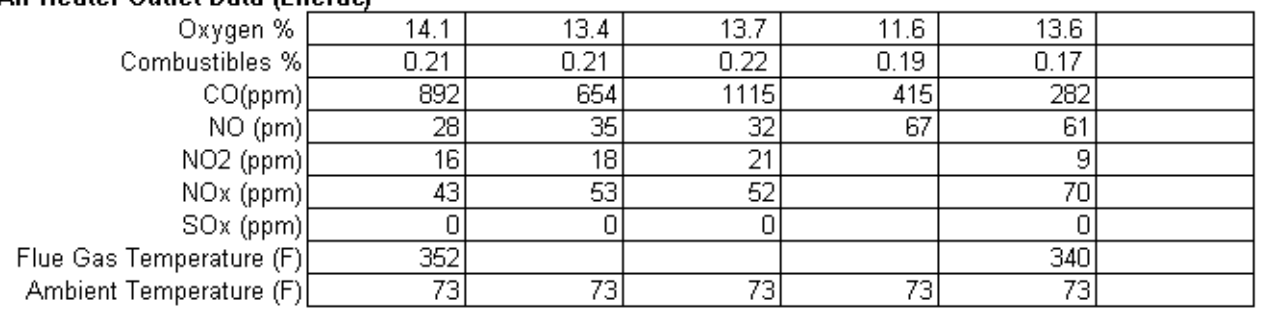

Figure A3. Boiler efficiency test data. 


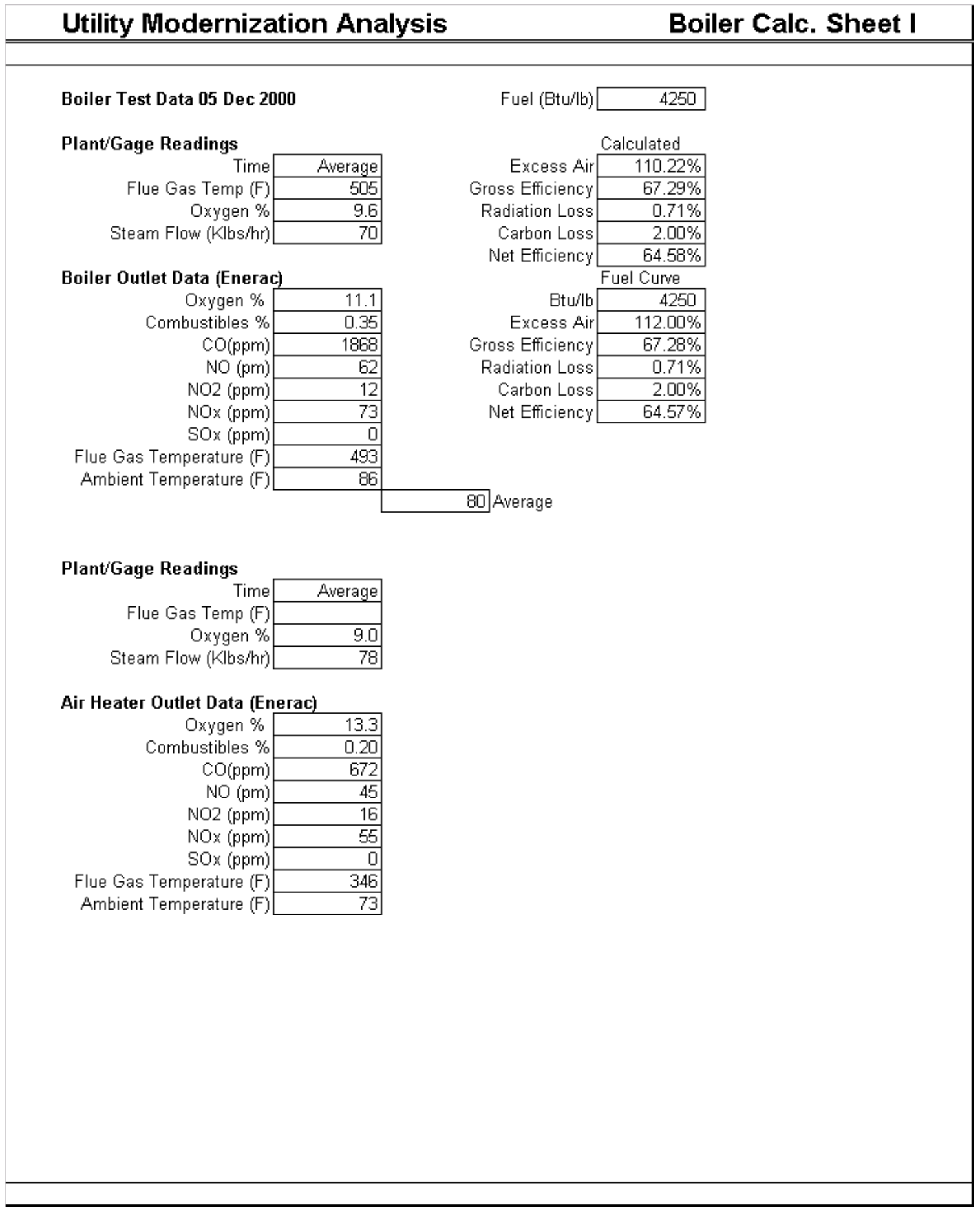

Figure A4. Boiler efficiency calculations. 


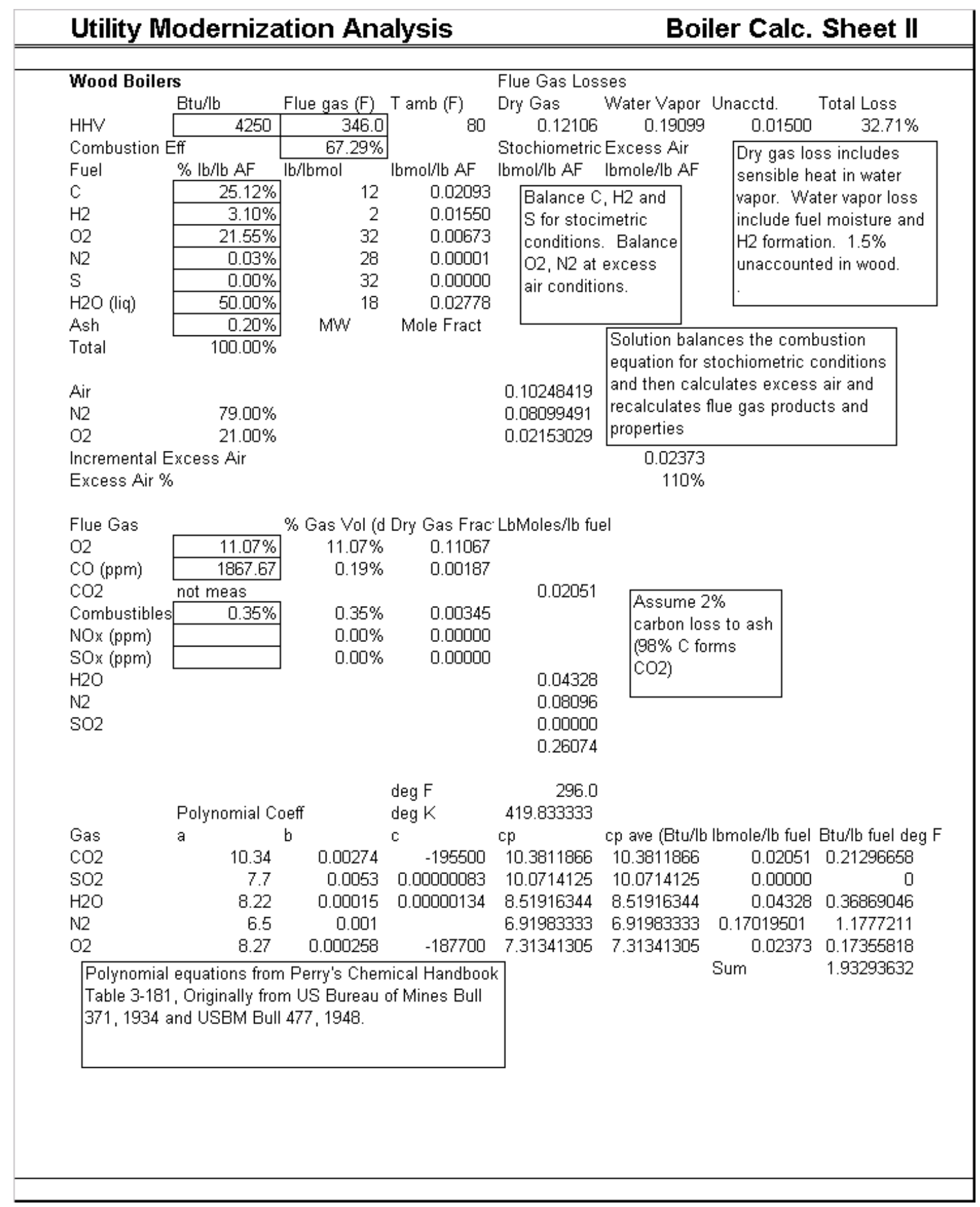

Figure A4. (Cont'd). 


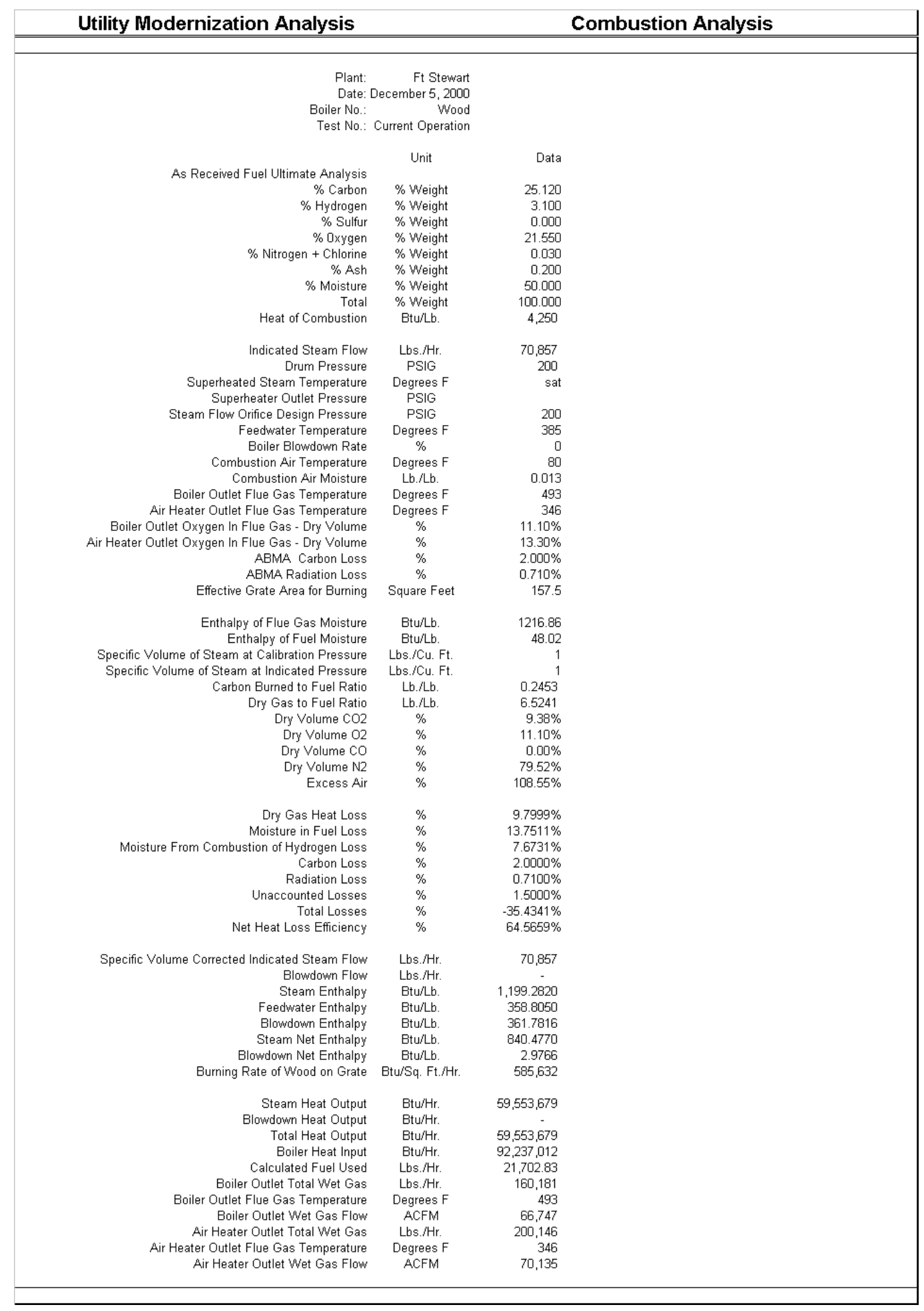

Figure A5. Combustion analysis. 


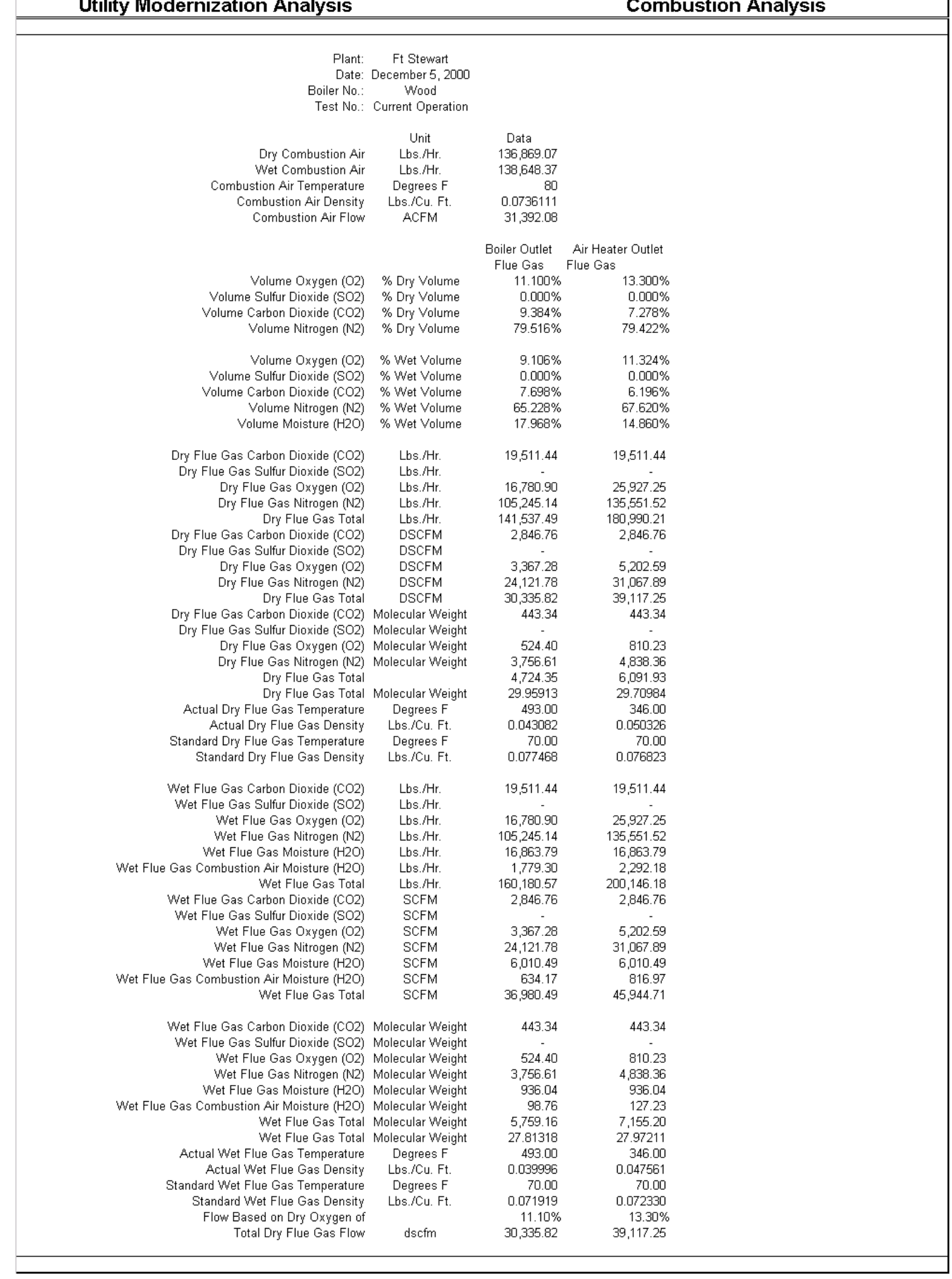

Figure A5. (Cont'd). 


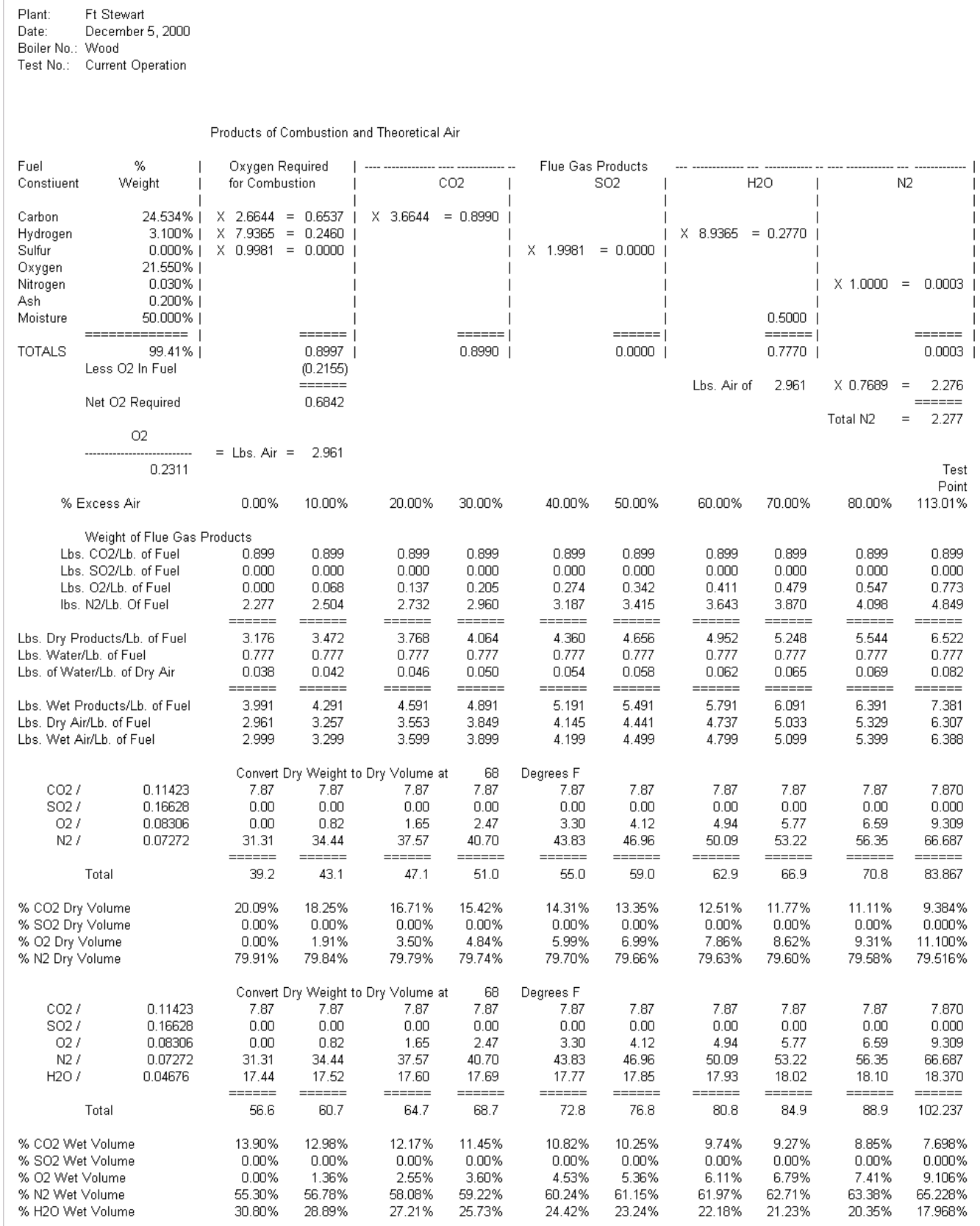

(n)

Weight of Flue Gas Products

Lbs. CO2/Lb. of Fuel $\quad 0.899$

Lbs. SO2/Lb. of Fuel $\quad 0.000 \quad 0.899$

Lbs. $02 /$ b. of Ful

lbs. N2/Lb. Of Fuel

Lbs. Dry Products/Lb. of Fuel Lbs. Water/Lb. of Fuel

Lbs. of Water/Lb. of Dry Air

Lbs. Wet Products/Lb. of Fuel Lbs. Dry Air/Lb. of Fuel

Lbs. Wet Air/Lb. of Fuel

\begin{tabular}{|c|c|}
\hline $\mathrm{CO} 2 /$ & 0.11423 \\
\hline $\mathrm{SO} 21$ & 0.16628 \\
\hline 021 & 0.08306 \\
\hline N2/ & 0.07272 \\
\hline \multicolumn{2}{|c|}{ Total } \\
\hline \multirow{4}{*}{\multicolumn{2}{|c|}{$\begin{array}{l}\% \text { CO2 Dry Volume } \\
\% \text { SO2 Dry Volume } \\
\% \text { O2 Dry Volume } \\
\% \text { N2 Dry Volume }\end{array}$}} \\
\hline & \\
\hline & \\
\hline & \\
\hline $\mathrm{CO} 2 /$ & 0.11423 \\
\hline $\mathrm{SO} 21$ & 0.16628 \\
\hline 027 & 0.08306 \\
\hline N2/ & 0.07272 \\
\hline $\mathrm{H} 2 \mathrm{O} /$ & 0.04676 \\
\hline
\end{tabular}

$\% \mathrm{CO} 2$ Wet Volume $\%$ SO2 Wet Volume $\%$ O2 Wet Volume $\%$ H2O Wet Volume

Lbs. Air of $2.961 \times 0.7689=2.276$ Total N2 $=2.277$ $40.00 \% \quad 50.00 \%$

$\begin{array}{rc}0.899 & 0.899 \\ 0.000 & 0.000 \\ 0.274 & 0.342 \\ 3.187 & 3.415 \\ ====== & ===== \\ 4.360 & 4.656 \\ 0.777 & 0.777 \\ 0.054 & 0.058 \\ ===== & ===== \\ 5.191 & 5.491 \\ 4.145 & 4.441 \\ 4.199 & 4.499\end{array}$
$\begin{array}{rccr}0.899 & 0.899 & 0.899 & 0.899 \\ 0.000 & 0.000 & 0.000 & 0.000 \\ 0.411 & 0.479 & 0.547 & 0.773 \\ 3.643 & 3.870 & 4.098 & 4.849 \\ ===== & ===== & ===== & ===== \\ 4.952 & 5.248 & 5.544 & 6.522 \\ 0.777 & 0.777 & 0.777 & 0.777 \\ 0.062 & 0.065 & 0.069 & 0.082 \\ ===== & ===== & ===== & ===== \\ 5.791 & 6.091 & 6.391 & 7.381 \\ 4.737 & 5.033 & 5.329 & 6.307 \\ 4.799 & 5.099 & 5.399 & 6.388\end{array}$ Degrees $\mathrm{F}$ $\begin{array}{cccr}\text { Convert Dry Weight to Dry Volume at } & 68 \\ 7.87 & 7.87 & 7.87 & 7.87\end{array}$ $\begin{array}{ll}7.87 & 7.87 \\ 0.00 & 0.00\end{array}$

$\begin{array}{rrrr}0.00 & 0.00 & 0.00 & 0.00 \\ 0.00 & 0.82 & 1.65 & 2.47 \\ 31.31 & 34.44 & 37.57 & 40.70\end{array}$

$\begin{array}{rrrr}31.31 & 34.44 & \begin{array}{r}37.57 \\ ====-\end{array} \quad \begin{array}{c}40.70 \\ ======\end{array} \\ 39.2 & 43.1 & 47.1 & 51.0\end{array}$

$20.09 \% \quad 18.25 \% \quad 16.71 \% \quad 15.42 \%$ $\begin{array}{rrrr}20.09 \% & 18.25 \% & 16.71 \% & 15.42 \% \\ 0.00 \% & 0.00 \% & 0.00 \% & 0.00 \%\end{array}$ $\begin{array}{rrrr}0.00 \% & 1.91 \% & 3.50 \% & 4.84 \% \\ 79.91 \% & 79.84 \% & 79.79 \% & 79.74 \%\end{array}$ $\begin{array}{ccrc}\text { Convert Dry Weight to Dry Volume at } & 68 & \text { Degrees F } \\ 787 & 787 & 787 & 787\end{array}$ $0.00 \quad 0.00$ $\begin{array}{rrrr}0.00 & 0.00 & 0.00 & 0.00 \\ 0.00 & 0.82 & 1.65 & 2.47 \\ 31.31 & 34.44 & 37.57 & 40.70\end{array}$ $=====\quad=====\quad=====\quad=====$ $\begin{array}{ll}7.87 & 7.87\end{array}$ 0.00
3.30 $\quad 0.00$ $=====\quad=====$ $\begin{array}{llll}7.87 & 7.87 & 7.87 & 7.870\end{array}$ $\begin{array}{llll}7.87 & 7.87 & 7.87 & 7.870 \\ 0.00 & 0.00 & 0.00 & 0.000 \\ 4.94 & 5.77 & 6.59 & 9.309\end{array}$ $\begin{array}{llll}4.94 & 5.77 & 6.59 & 9.309\end{array}$ $\begin{array}{llll}50.09 & 53.22 & 56.35 & 66.687\end{array}$ $\begin{array}{llll}62.9 & 66.9 & 70.8 & 83.867\end{array}$

$12.51 \% \quad 11.77 \% \quad 11.11 \% \quad 9.384 \%$

$\begin{array}{llll}0.00 \% & 0.00 \% & 0.00 \% & 0.000 \%\end{array}$

$\begin{array}{rrrr}7.86 \% & 8.62 \% & 9.31 \% & 11.100 \% \\ 79.63 \% & 79.60 \% & 79.58 \% & 79.516 \%\end{array}$ $0.00 \% \quad 0.00 \%$ $\begin{array}{rr}5.99 \% & 6.99 \% \\ 79.70 \% & 79.66 \%\end{array}$ 7.87
0.00

$\begin{array}{rc}7.87 & 7.87 \\ 0.00 & 0.00 \\ 3.30 & 4.12 \\ 43.83 & 46.96 \\ 17.77 & 17.85 \\ ====== & ===== \\ 72.8 & 76.8 \\ & \\ 10.82 \% & 10.25 \% \\ 0.00 \% & 0.00 \% \\ 4.53 \% & 5.36 \% \\ 60.24 \% & 61.15 \% \\ 24.42 \% & 23.24 \%\end{array}$

$\begin{array}{rrrr}7.87 & 7.87 & 7.87 & 7.870 \\ 0.00 & 0.00 & 0.00 & 0.000 \\ 4.94 & 5.77 & 6.59 & 9.309 \\ 50.09 & 53.22 & 56.35 & 66.687 \\ 17.93 & 18.02 & 18.10 & 18.370 \\ ===== & ====== & ===== & ===== \\ 80.8 & 84.9 & 88.9 & 102.237 \\ & & & \\ 9.74 \% & 9.27 \% & 8.85 \% & 7.698 \% \\ 0.00 \% & 0.00 \% & 0.00 \% & 0.000 \% \\ 6.11 \% & 6.79 \% & 7.41 \% & 9.106 \% \\ 61.97 \% & 62.71 \% & 63.38 \% & 65.228 \% \\ 22.18 \% & 21.23 \% & 20.35 \% & 17.968 \%\end{array}$

Figure A5. (Cont'd). 


\section{Appendix B: Site Visit Photos from Fort Stewart}

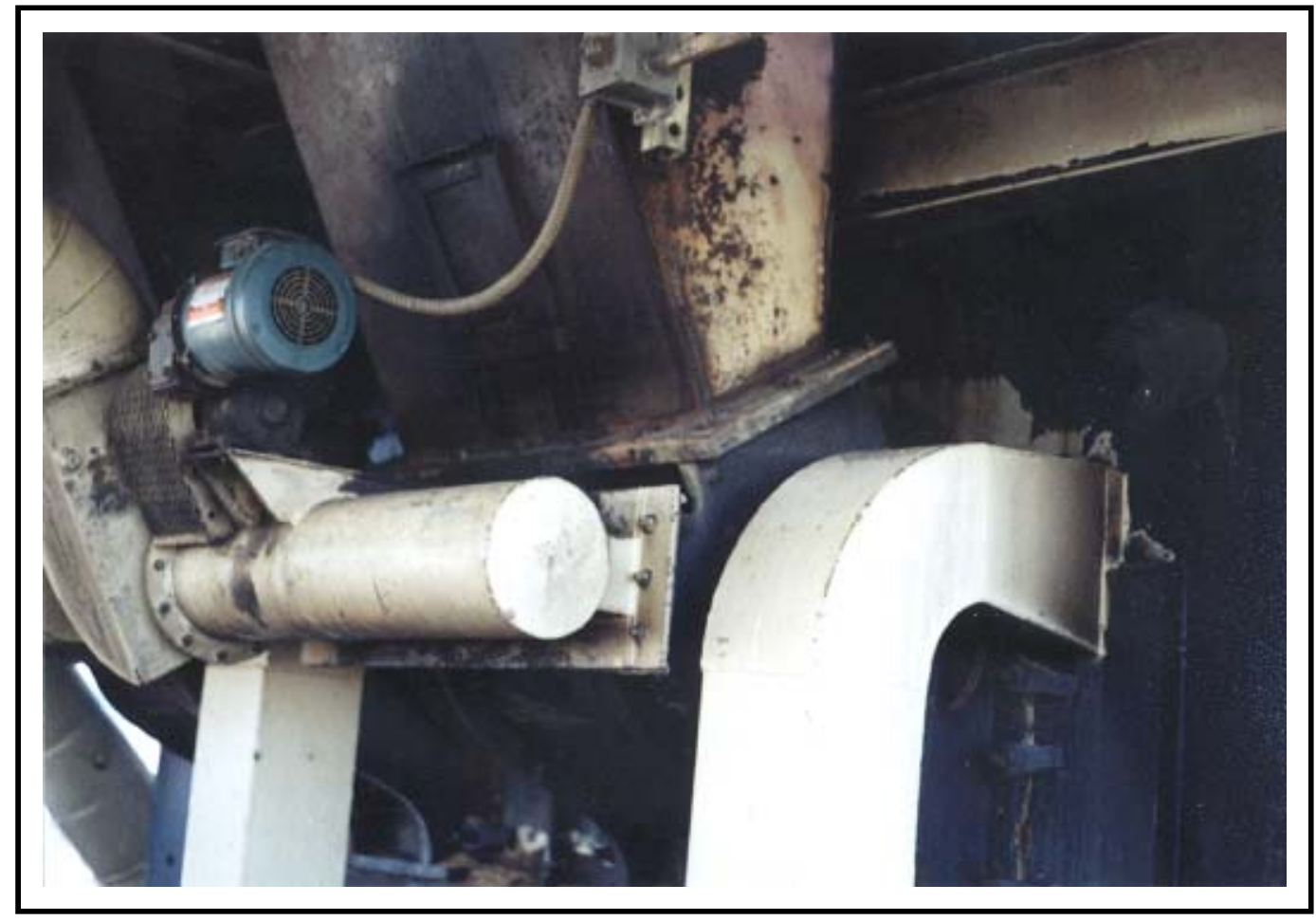

Figure B1. Wood feeder. 


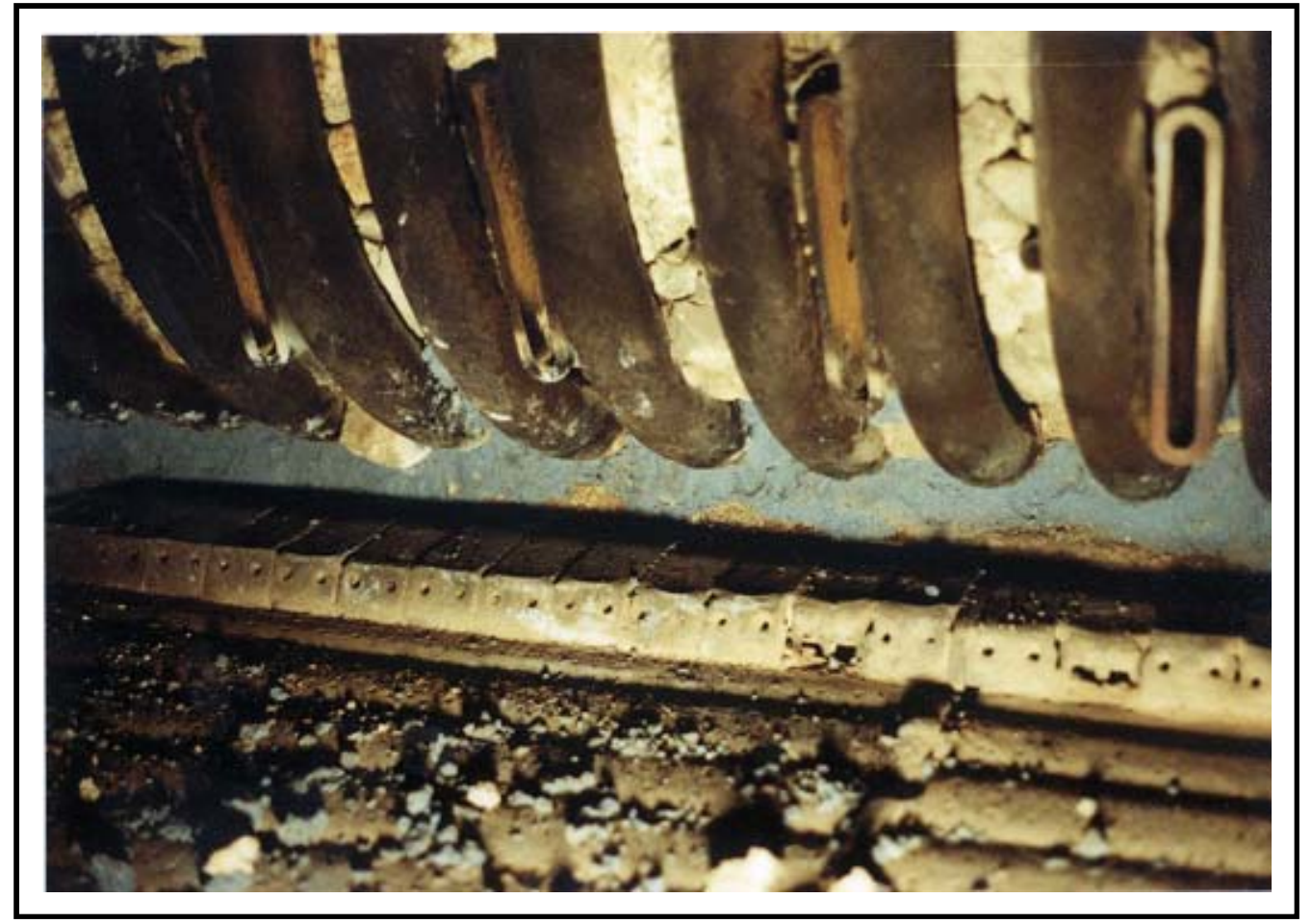

Figure B2. Rear of grate.

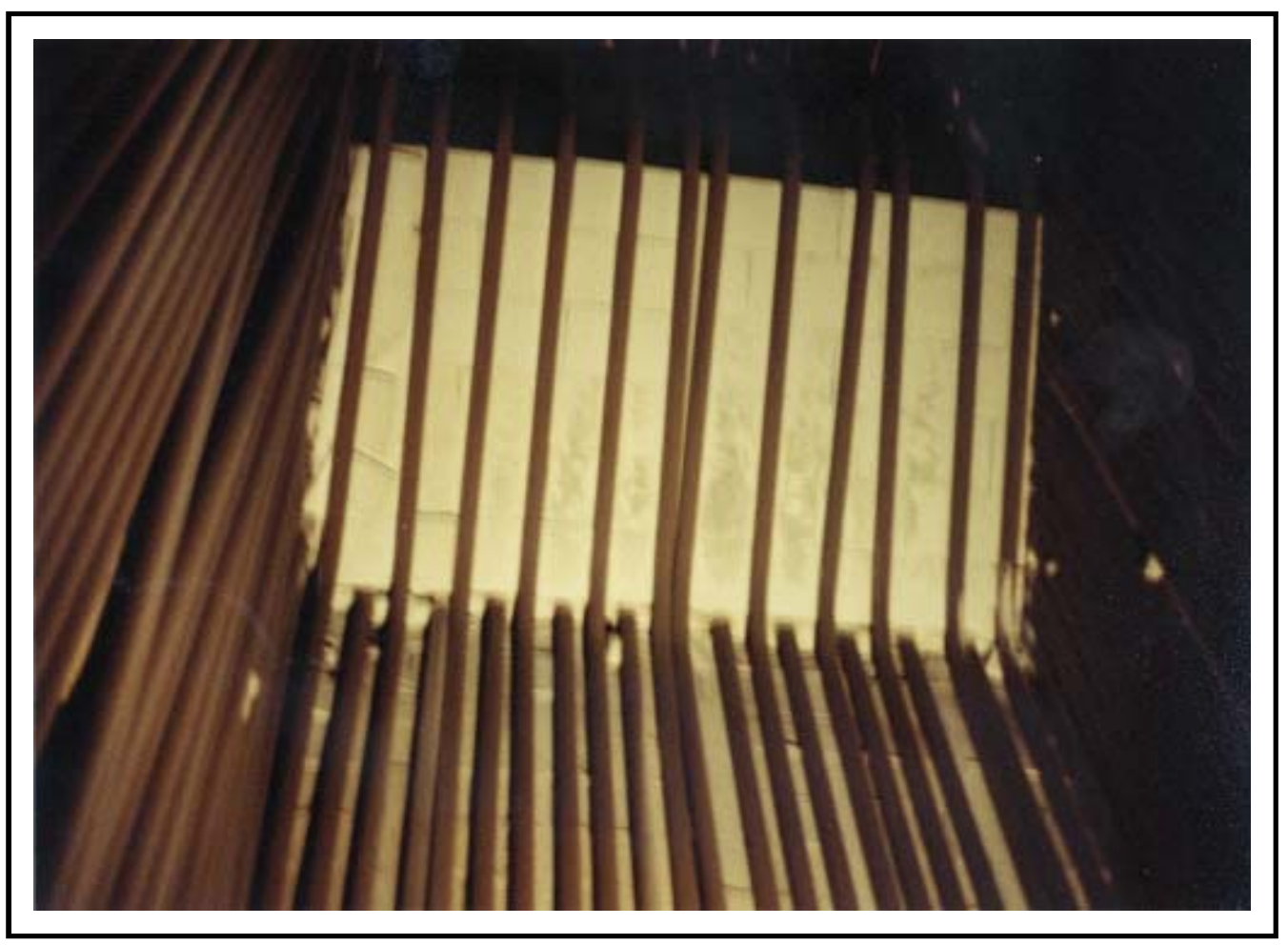

Figure B3. Upper rear wall. 


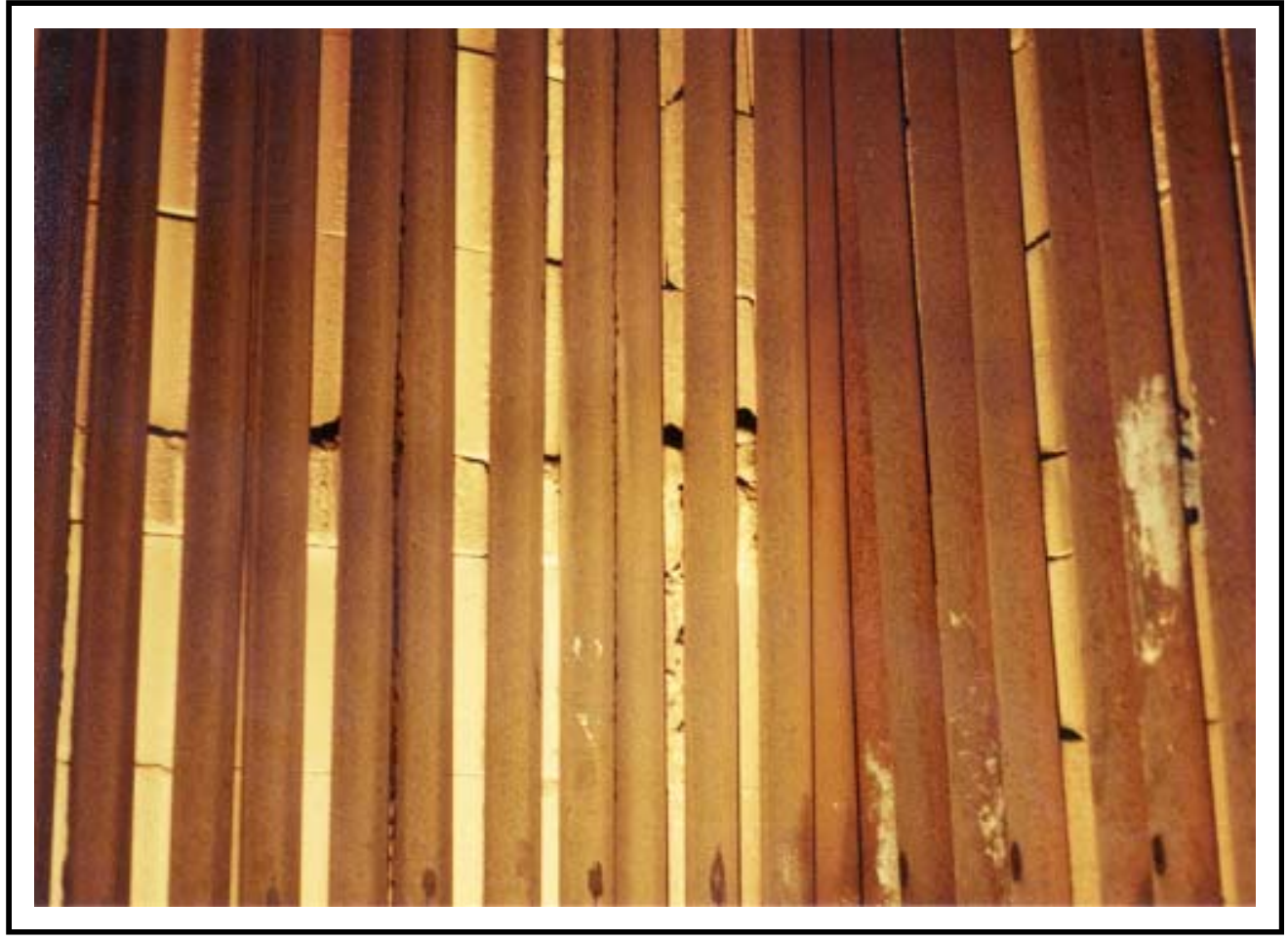

Figure B4. Left rear corner.

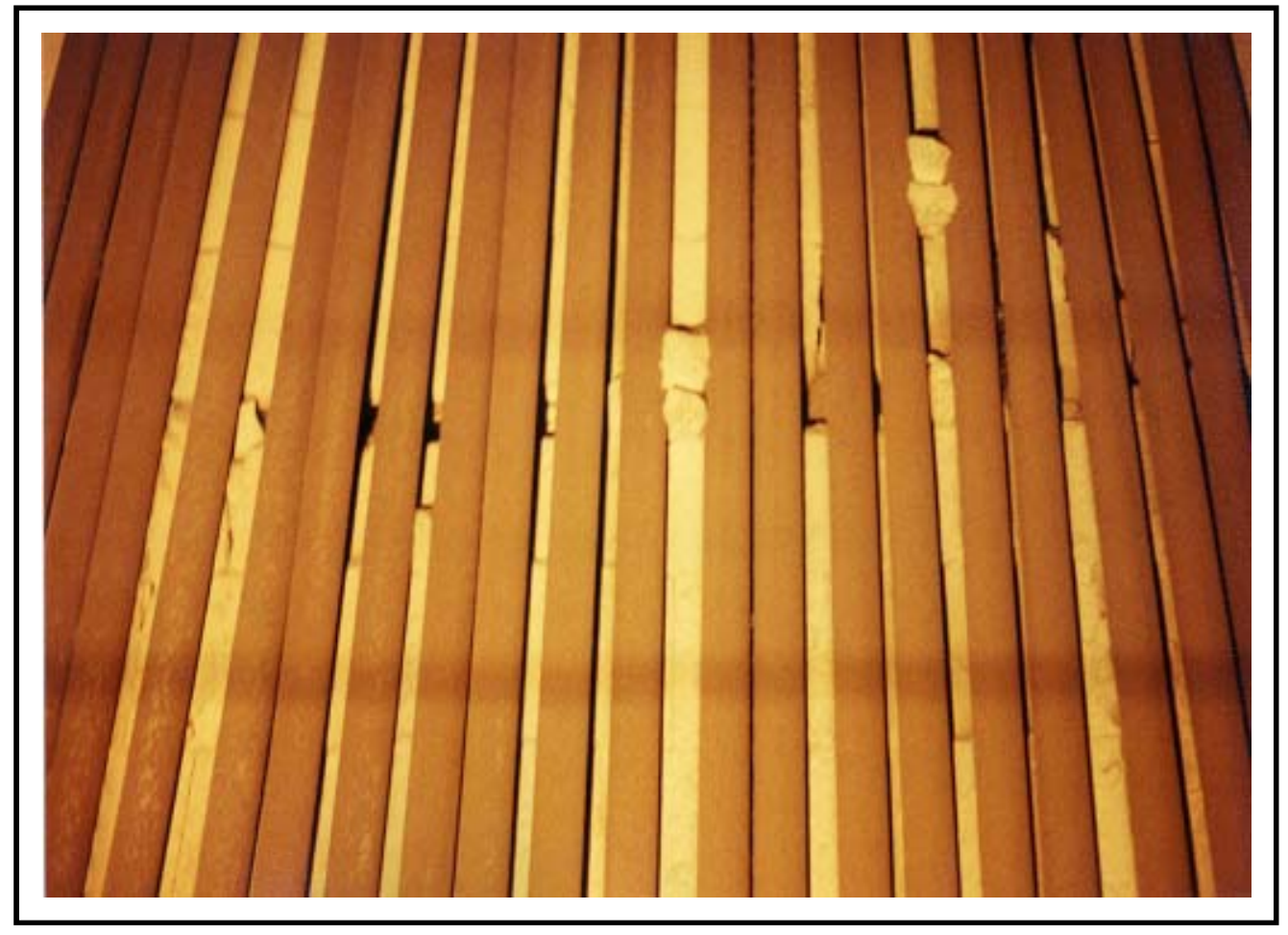

Figure B5. Left wall. 


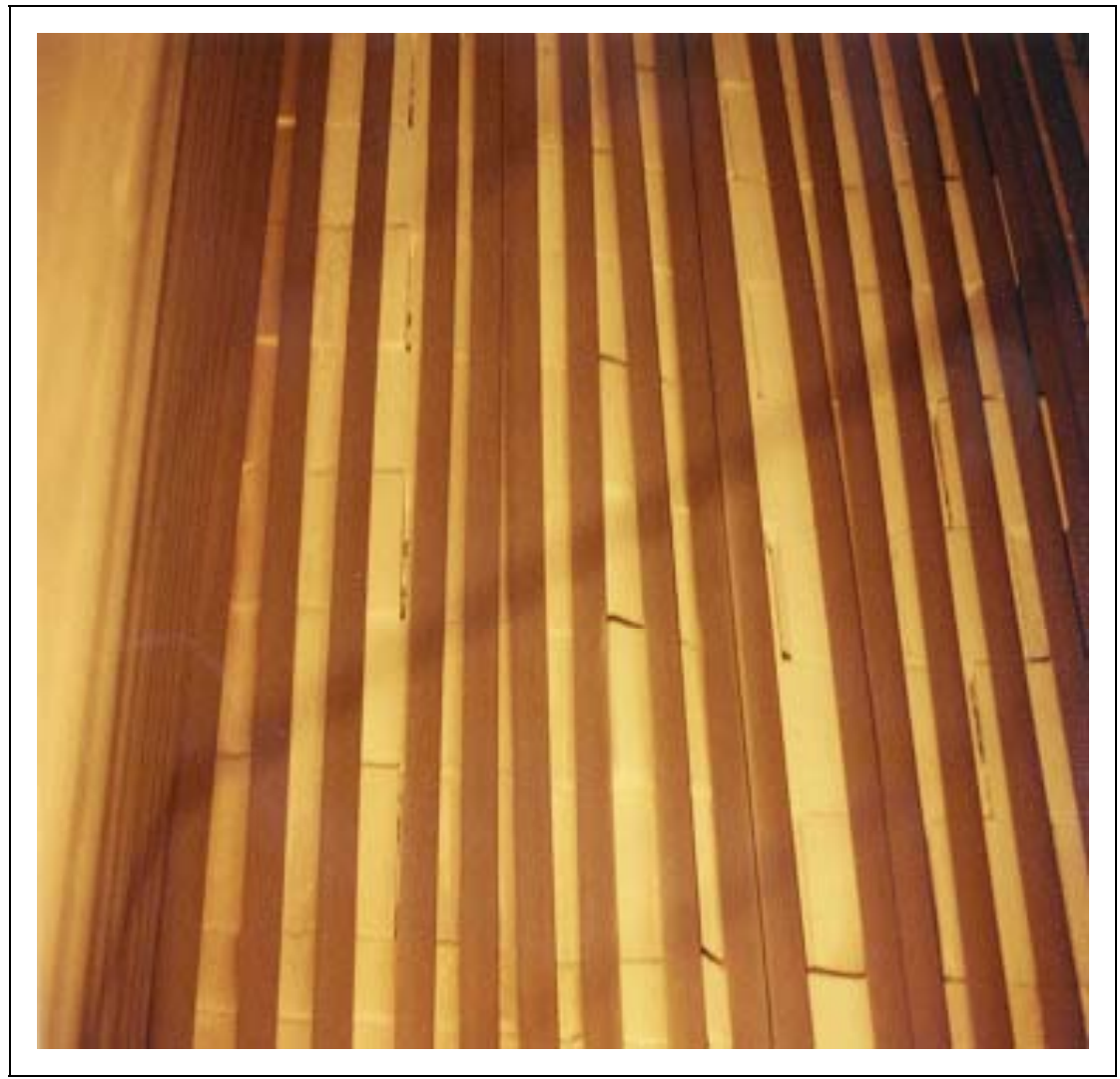

Figure B6. Left wall.

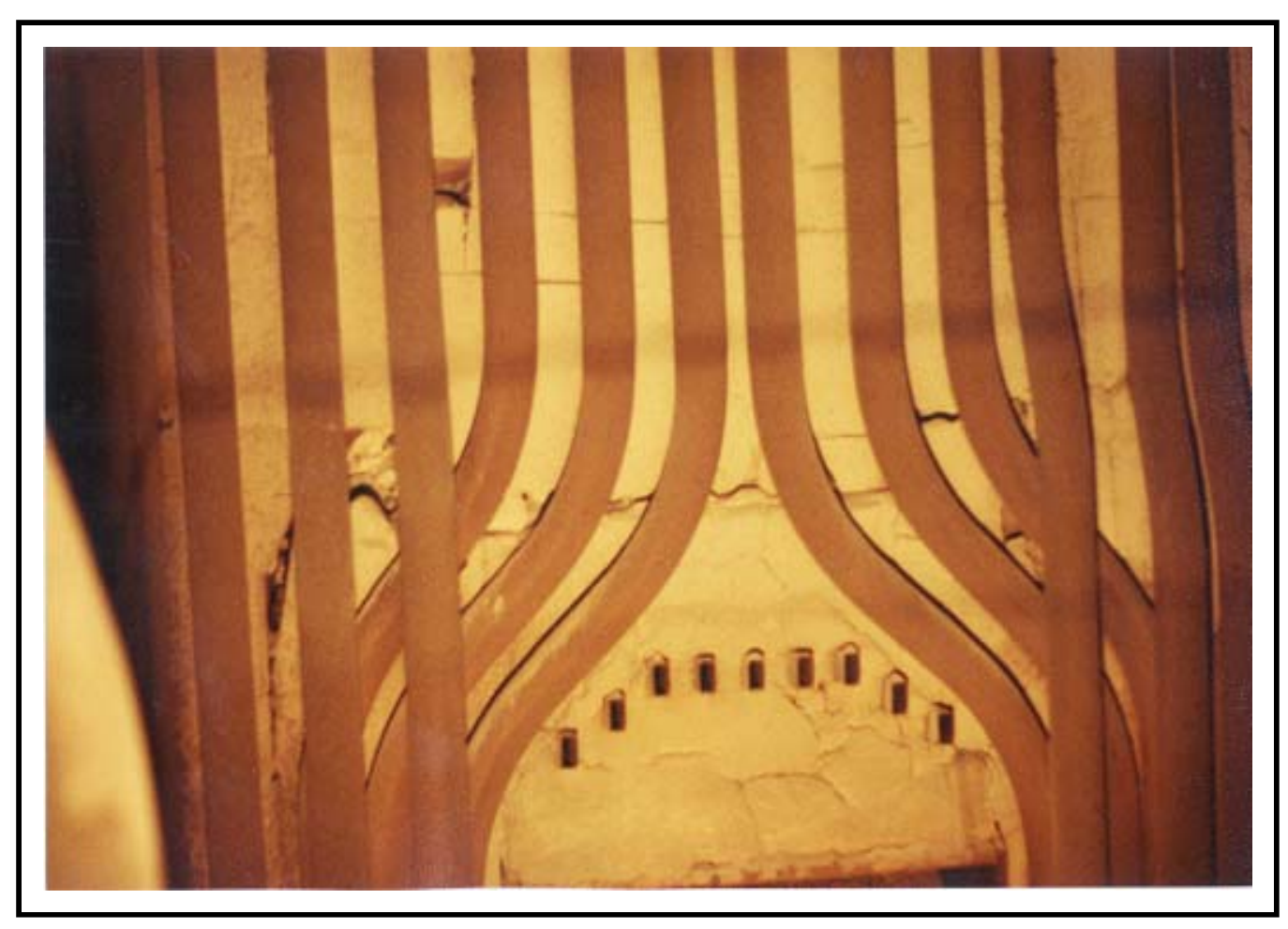

Figure B7. Front wall above feeder. 


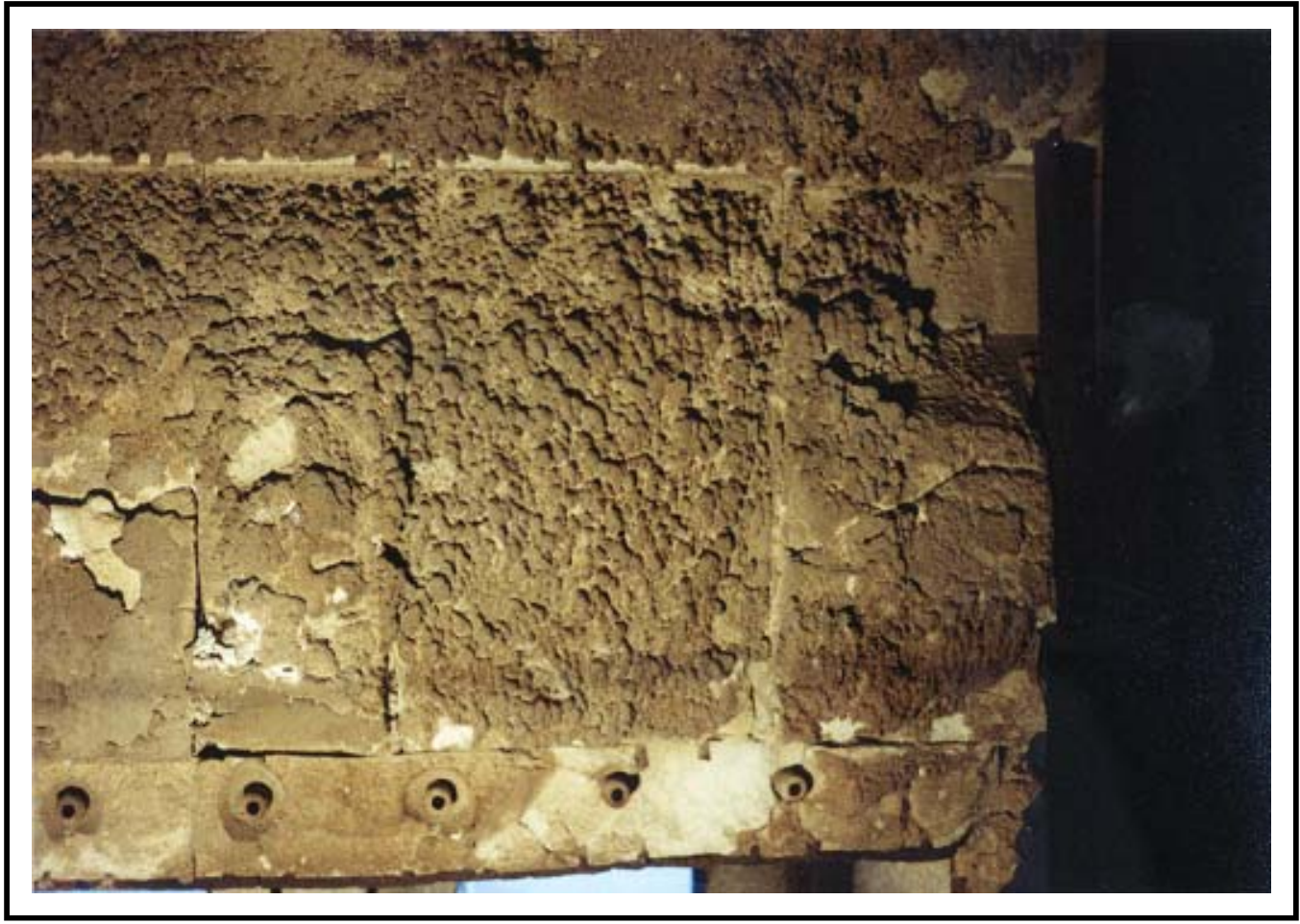

Figure B8. Front refractory and over-fire air nozzles.

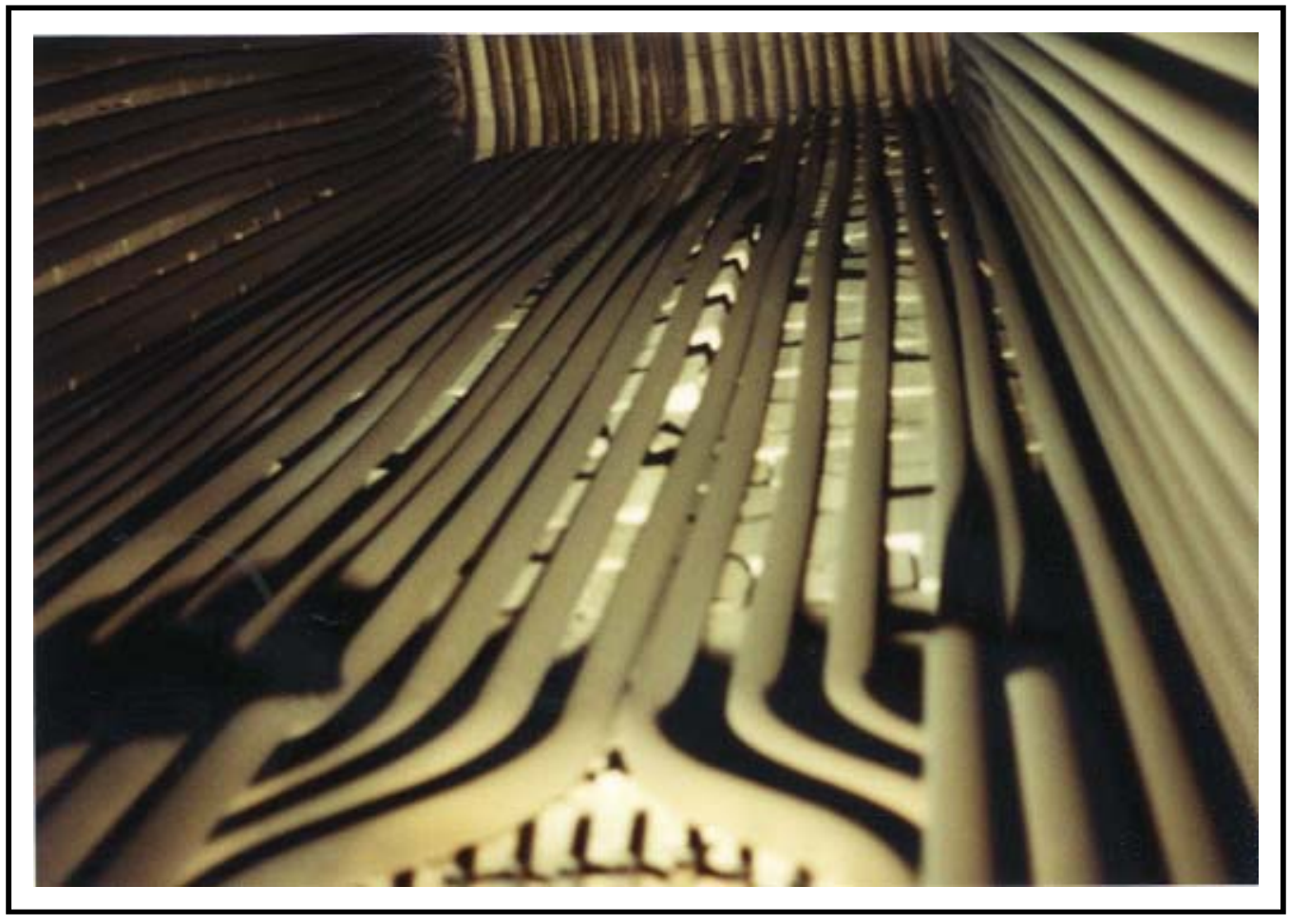

Figure B9. Front wall. 


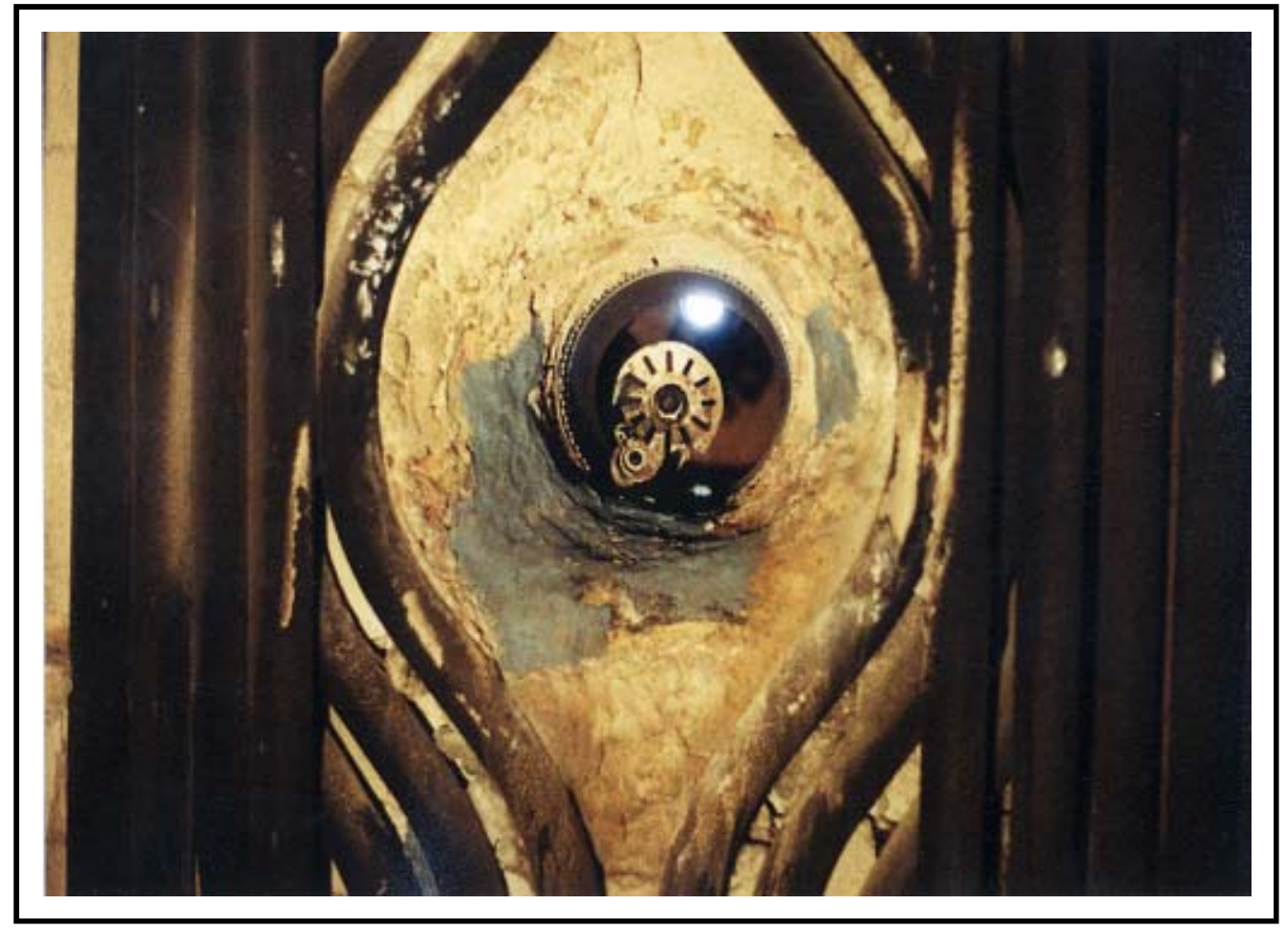

Figure B10. Right wall burner.

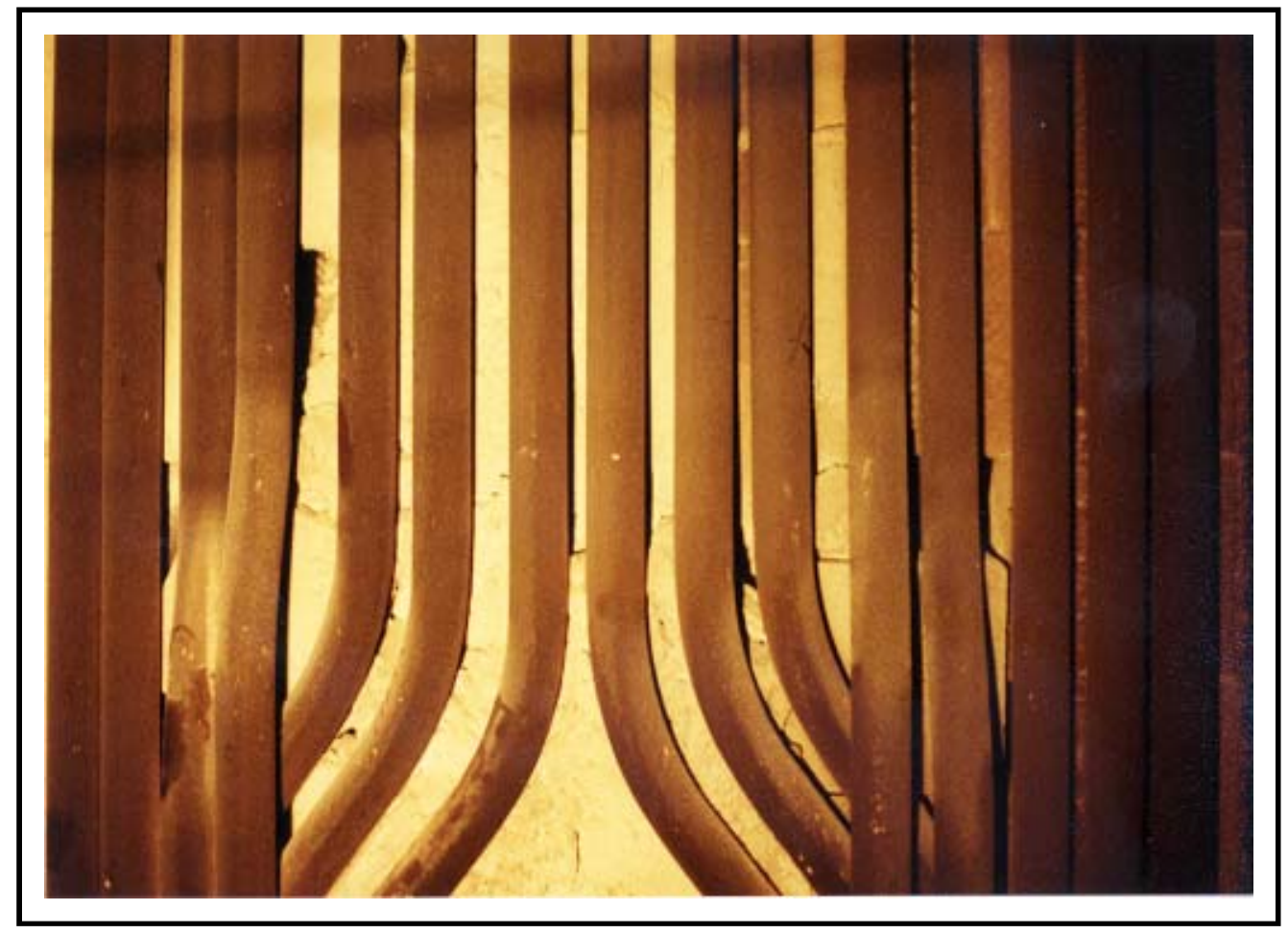

Figure B11. Right wall above burner. 


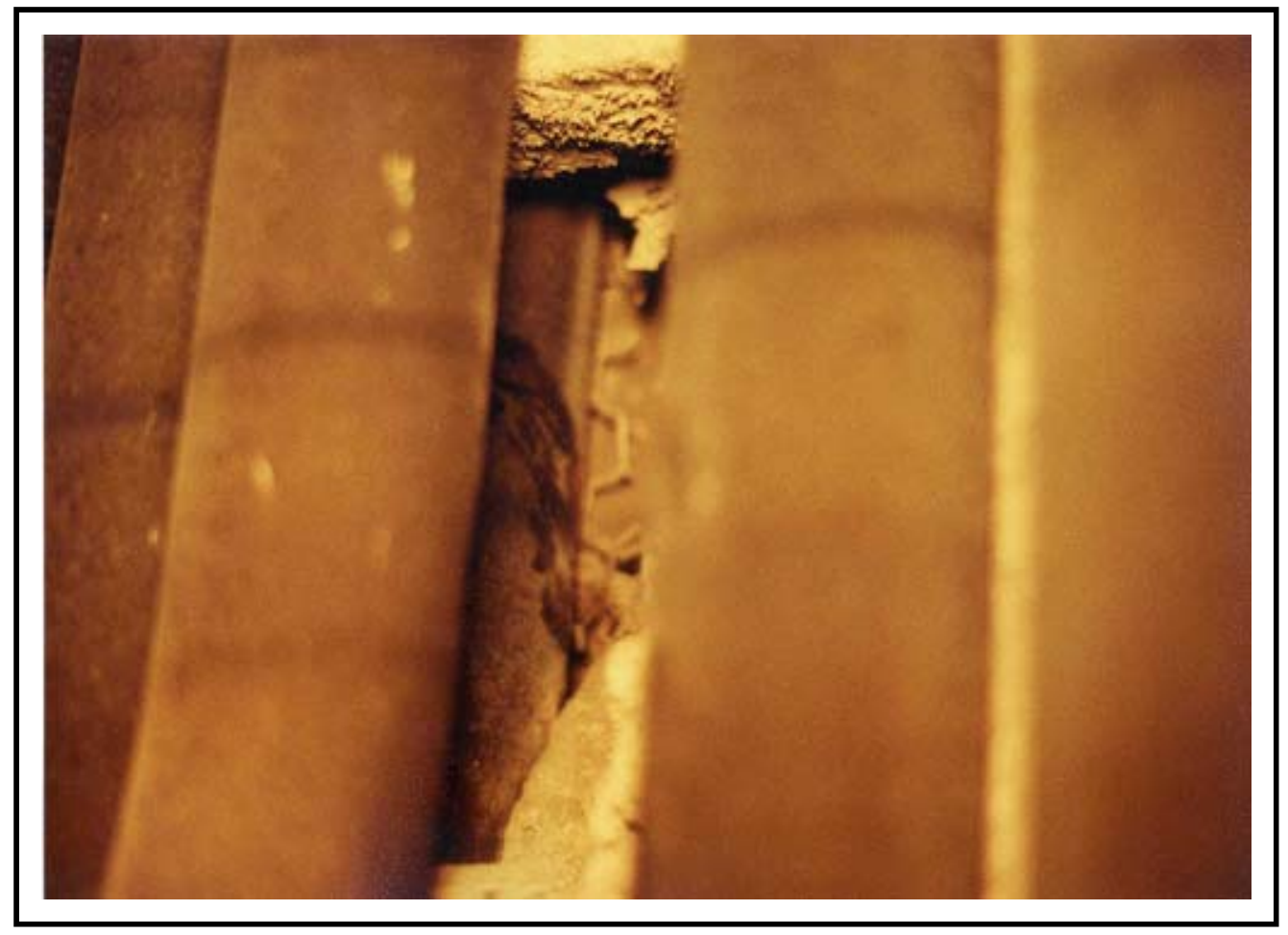

Figure B12. Right wall above and left of burner.

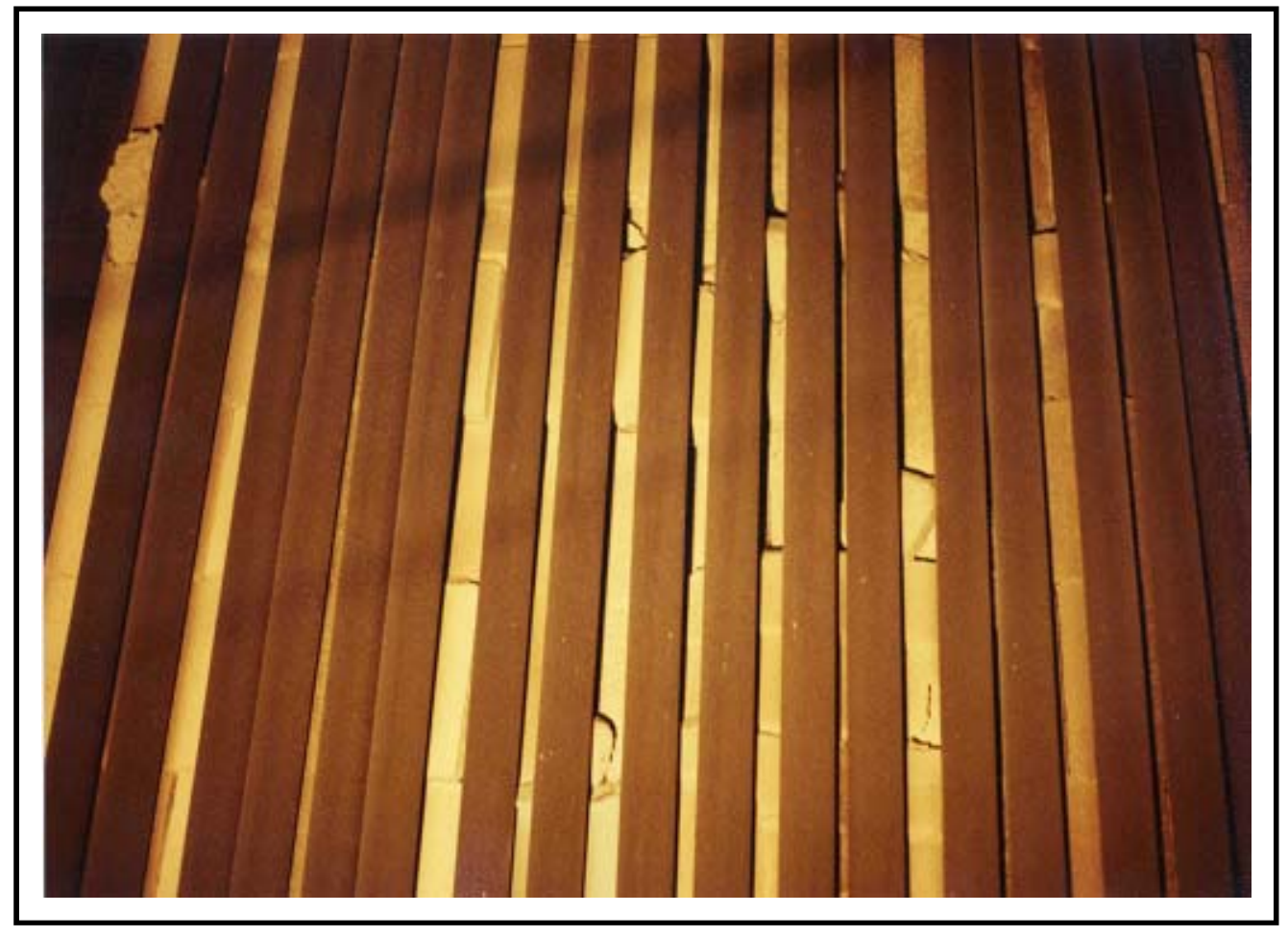

Figure B13. Right wall. 


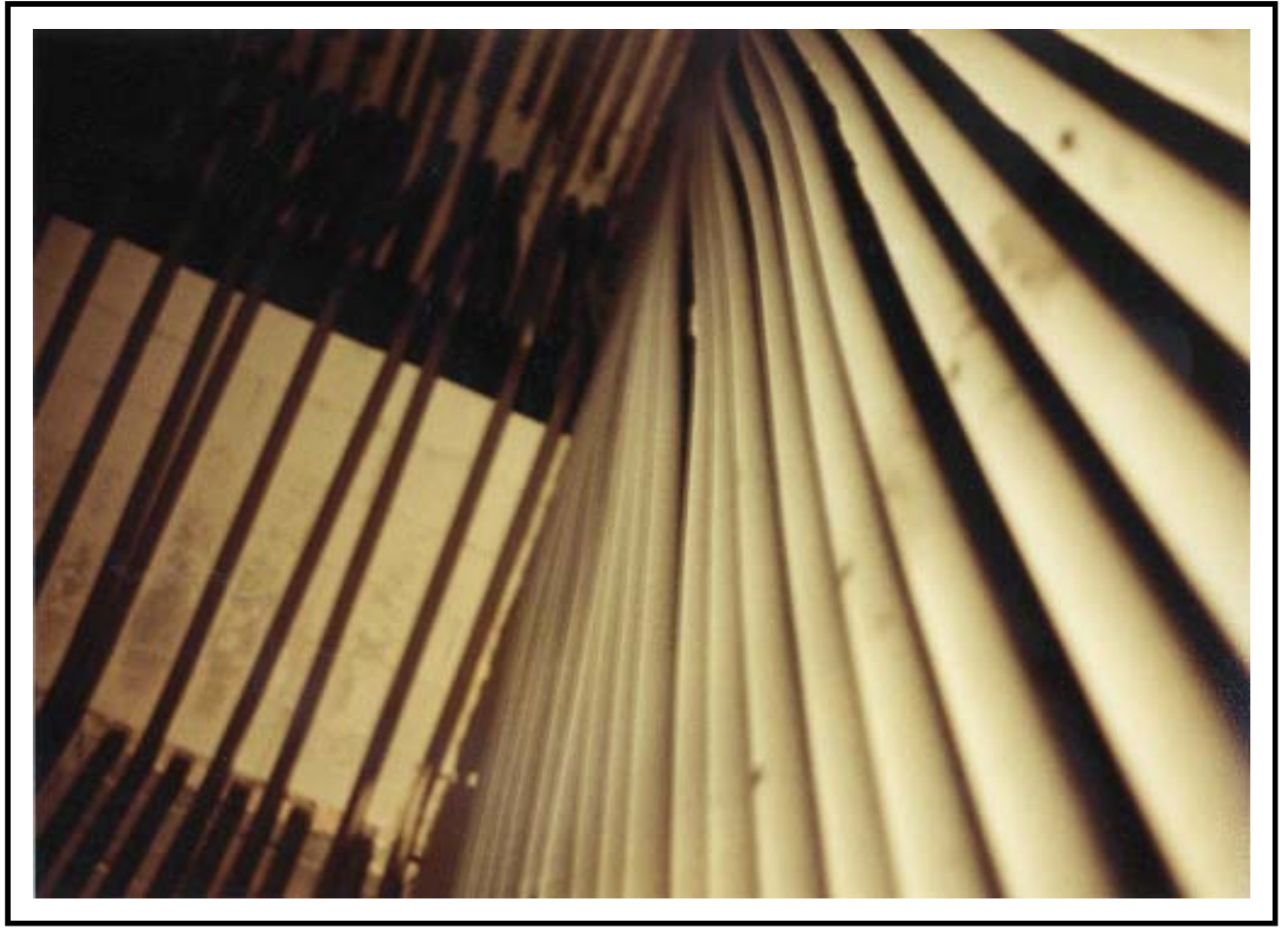

Figure B14. Right wall. 


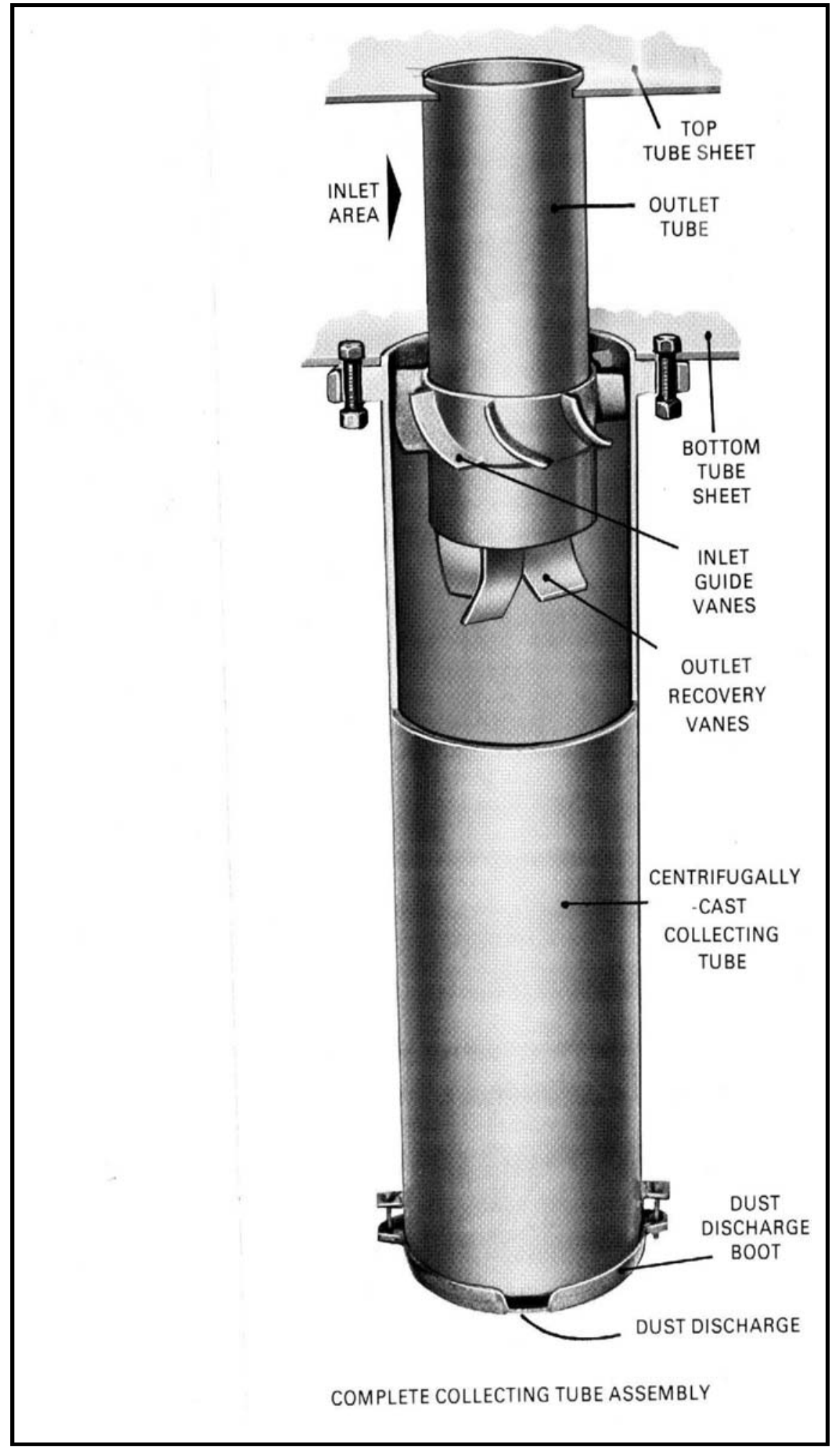

Figure B15. Zurn collector tube. 


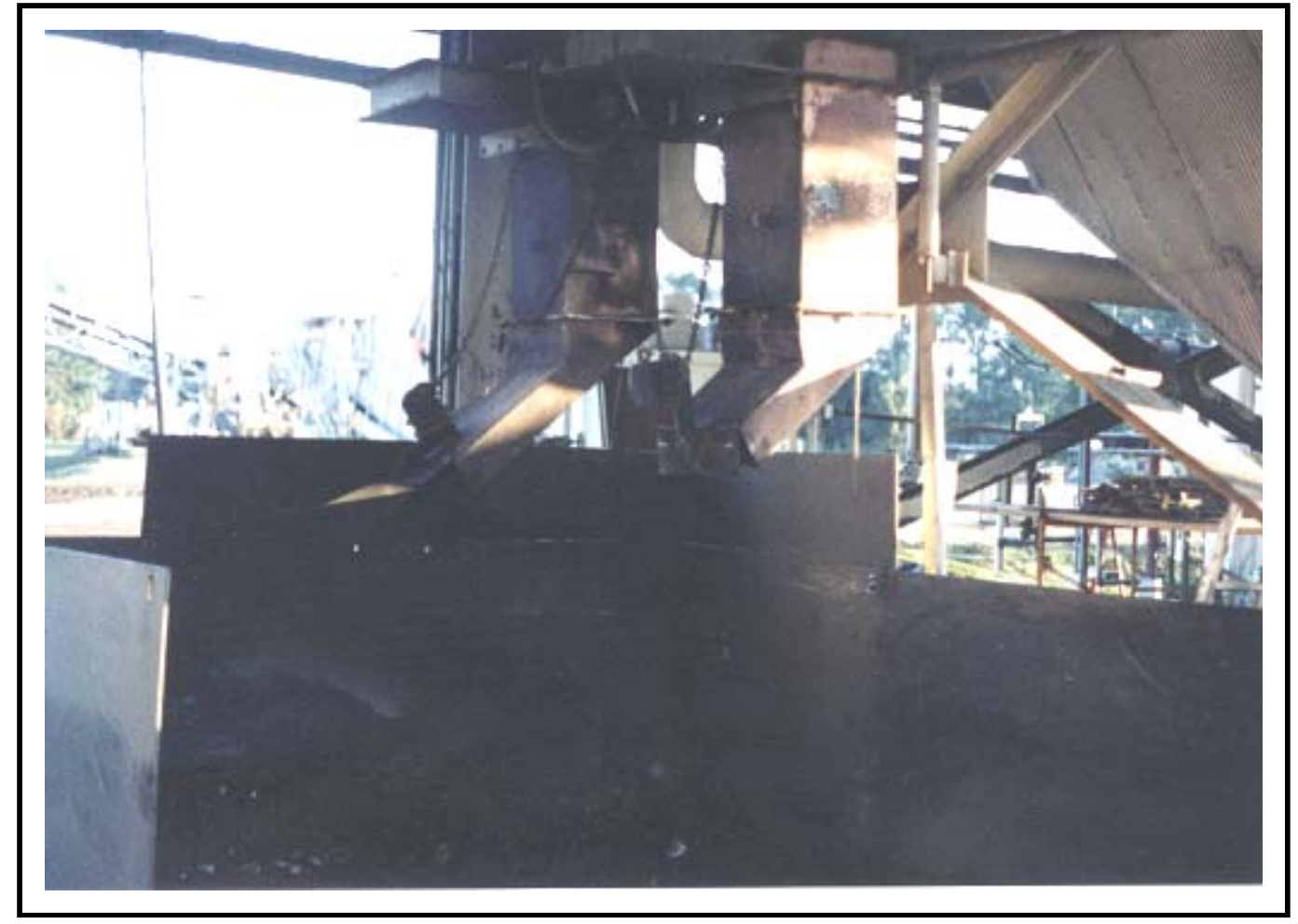

Figure B16. Bottom ash chutes.

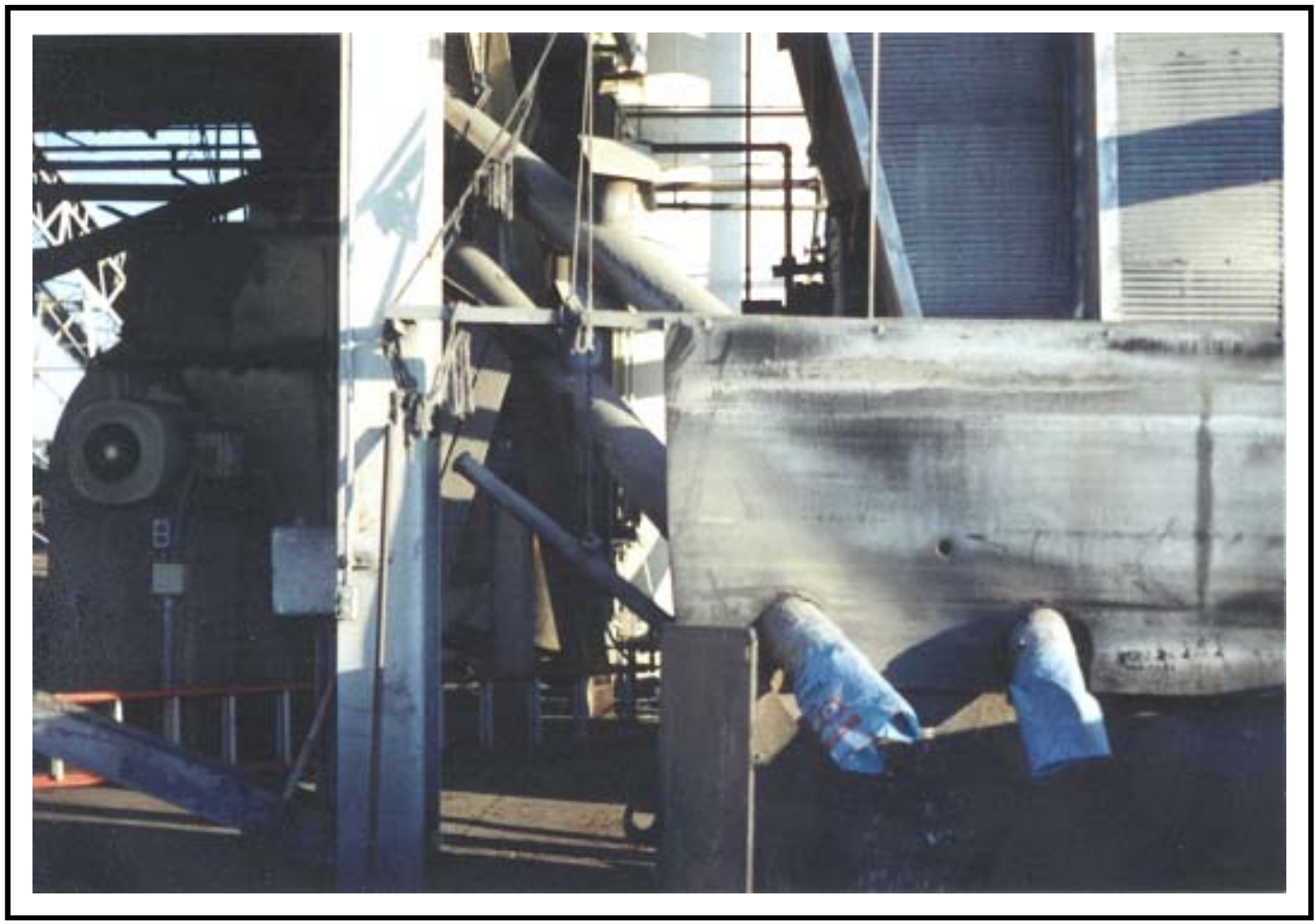

Figure B17. Flyash chutes. 


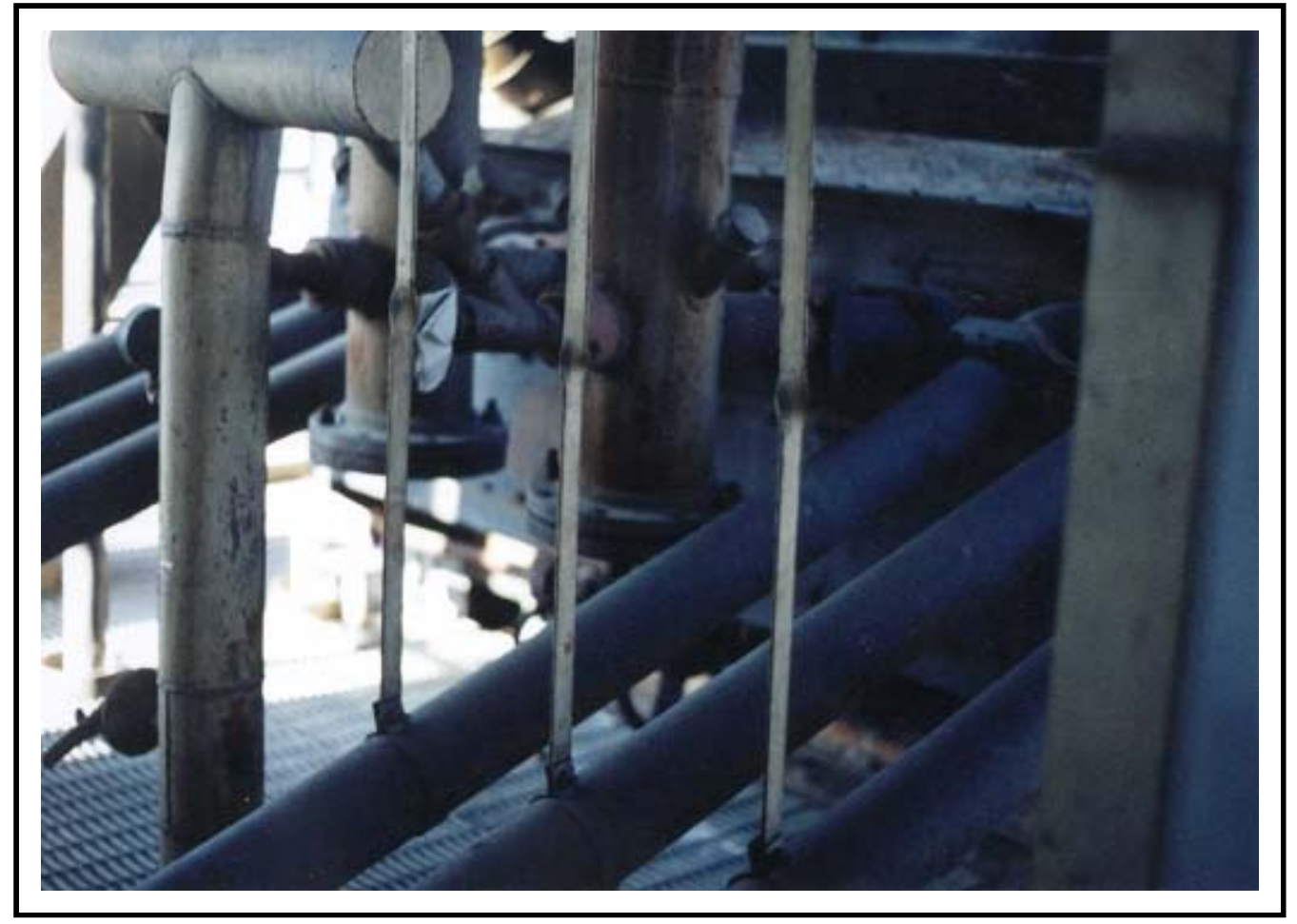

Figure B18. Reinjection system.

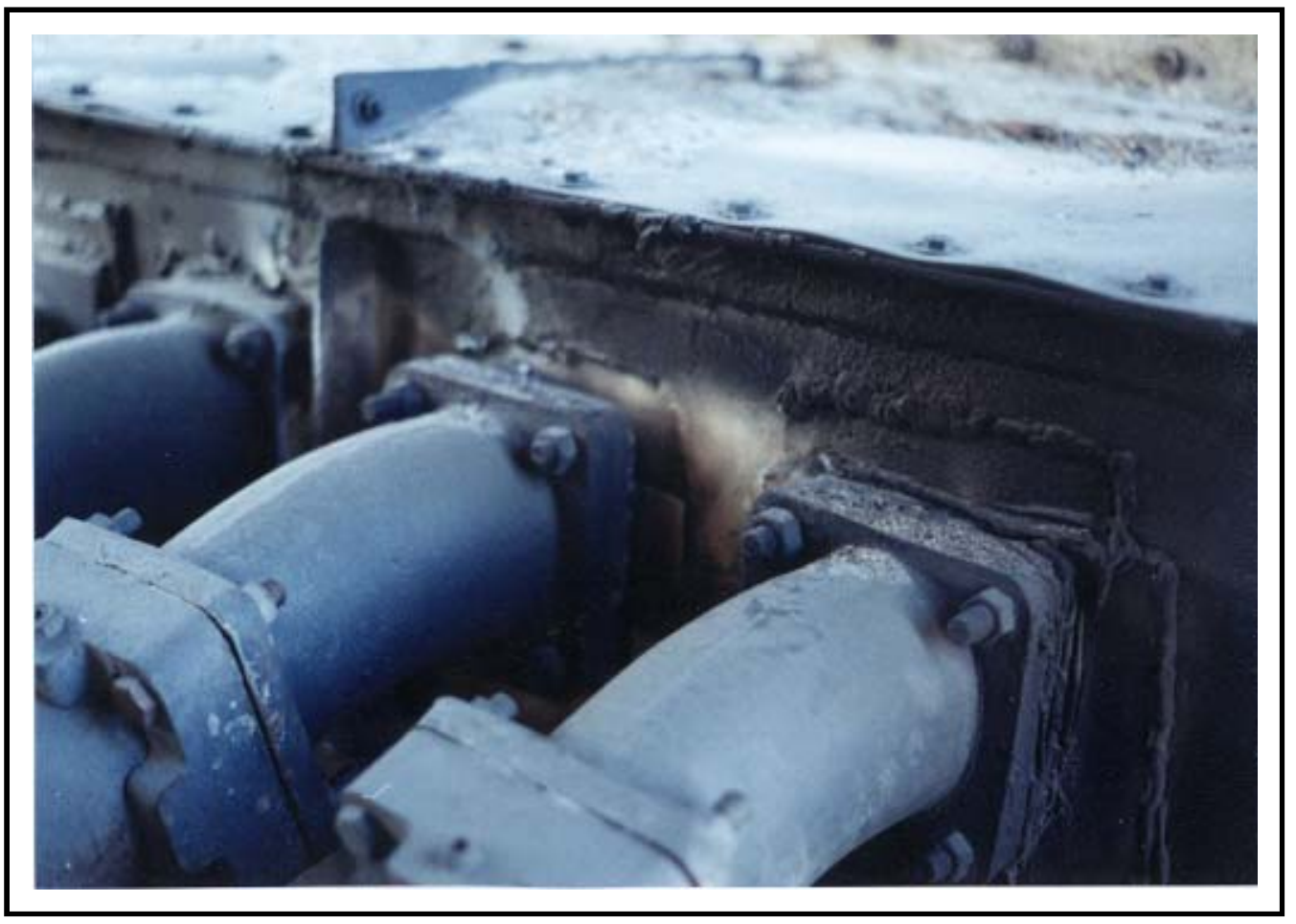

Figure B19. Reinjection connections. 


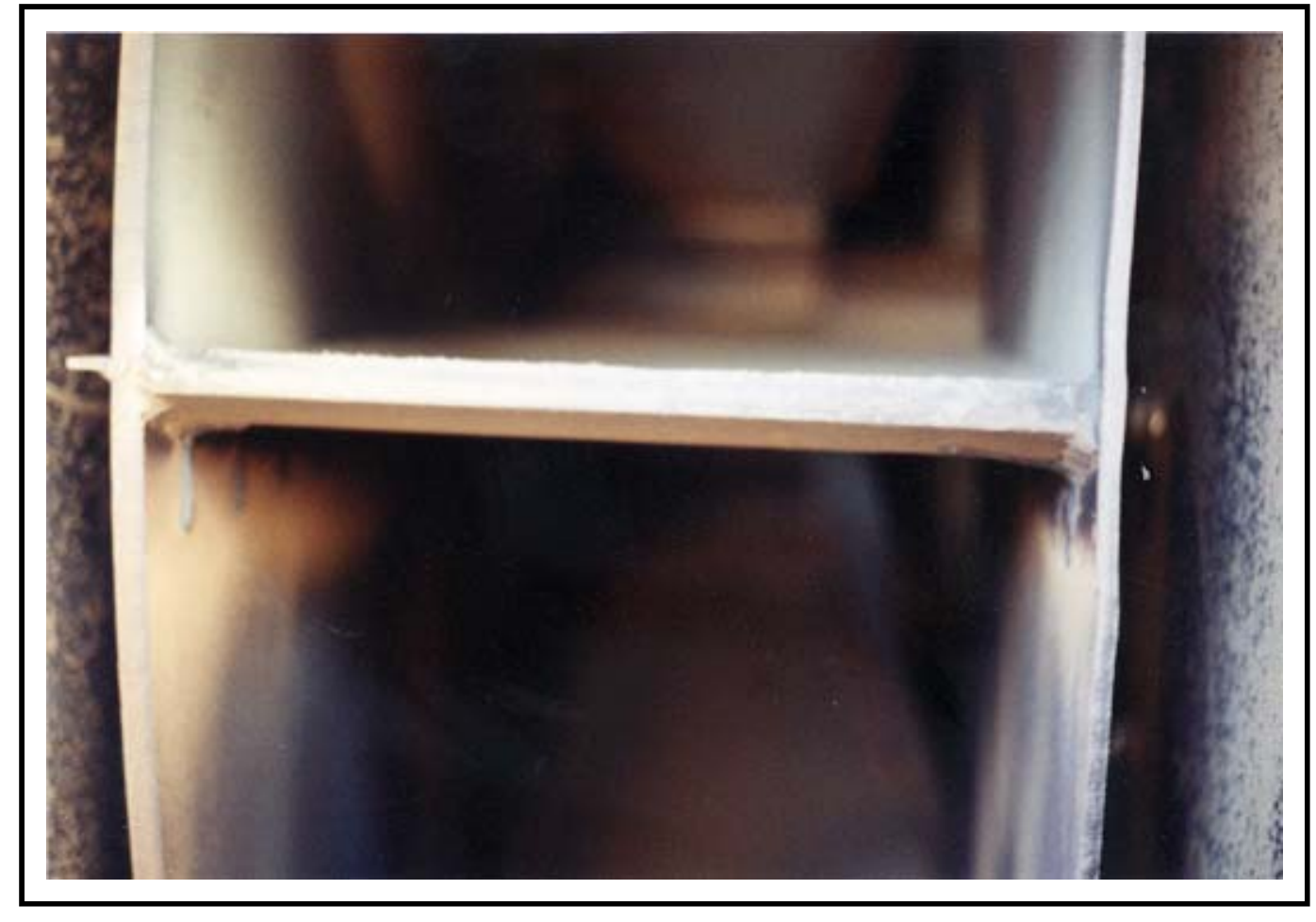

Figure B20. ID fan wheel. 


\section{CERL Distribution}

Commander, Fort Stewart, GA

ATTN: DPW Energy Office (4)

Chief of Engineers

ATTN: CEHEC-IM-LH (2)

Engineer Research and Development Center (Libraries)

ATTN: ERDC, Vicksburg, MS

ATTN: Cold Regions Research, Hanover, NH

ATTN: Topographic Engineering Center, Alexandria, VA

Defense Tech Info Center 22304

ATTN: DTIC-O

9

$9 / 02$ 


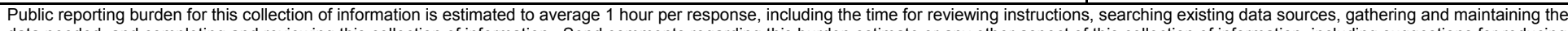

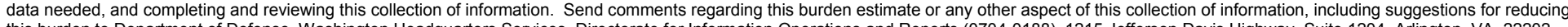

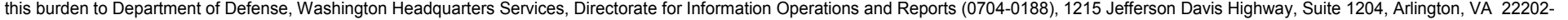

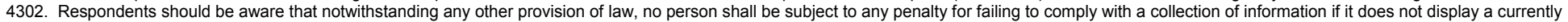
valid OMB control number. PLEASE DO NOT RETURN YOUR FORM TO THE ABOVE ADDRESS.

\section{\begin{tabular}{l|l} 
1. REPORT DATE (DD-MM-YYYY) & 2. REPORT TYPE
\end{tabular}} 08-2002

4. TITLE AND SUBTITLE Final

3. DATES COVERED (From - To)

Wood-Fired Boiler System Evaluation at Fort Stewart, GA

5a. CONTRACT NUMBER

5b. GRANT NUMBER

5c. PROGRAM ELEMENT NUMBER

6. AUTHOR(S)

Noel L. Potts and Charles M. Schmidt

5d. PROJECT NUMBER

MIPR

5e. TASK NUMBER

OMCER5A190; OMCER5A190

5f. WORK UNIT NUMBER

\section{PERFORMING ORGANIZATION NAME(S) AND ADDRESS(ES)}

U.S. Army Engineer Research and Development Center (ERDC)

Construction Engineering Research Laboratory (CERL)

8. PERFORMING ORGANIZATION REPORT NUMBER

PO Box 9005

Champaign, IL 61826-9005

ERDC/CERL TR-02-23

9. SPONSORING / MONITORING AGENCY NAME(S) AND ADDRESS(ES)

10. SPONSOR/MONITOR'S ACRONYM(S)

3D IN Div (Mech) and Fort Stewart

Directorate of Public Works, Energy Office

1117 Frank Cochran Drive, Suite 101

Fort Stewart, GA 31314-4940

11. SPONSOR/MONITOR'S REPORT NUMBER(S)

12. DISTRIBUTION / AVAILABILITY STATEMENT

Approved for public release; distribution is unlimited.

\section{SUPPLEMENTARY NOTES}

Copies are available from the National Technical Information Service, 5285 Port Royal Road, Springfield, VA 22161.

\section{ABSTRACT}

Part of the plan to modernize the central energy plant (CEP) at Fort Stewart, GA is focused on the installation's wood-fired boiler, which provides steam for heating, cooling, and domestic hot water. The U.S. Army Engineer Research and Development Center, Construction Engineering Research Laboratory (ERDC/CERL) was tasked with supporting Fort Stewart in planning its CEP modernization. Researchers made site visits 1-3 November 2000 and 5-6 December 2000, inspected the CEP equipment and evaluated its condition, conducted operational tests, made "cold iron" inspections, and reviewed plant logs. Researchers recorded and analyzed the results of the inspections and tests, and outlined two alternative options, which specify the improvements and repairs needed to extend the system life.

\section{SUBJECT TERMS}

boilers central energy plant (CEP)

\section{SECURITY CLASSIFICATION OF:}

a. REPORT

Unclassified

b. ABSTRACT

Unclassified

c. THIS PAGE

Unclassified

cooling systems

heat distribution systems
Ft. Stewart, GA

wood-fired boilers

\begin{tabular}{|c|c|}
$\begin{array}{c}\text { 17. LIMITATION } \\
\text { OF ABSTRACT }\end{array}$ & $\begin{array}{c}\text { 18. NUMBER } \\
\text { OF PAGES }\end{array}$ \\
SAR & 41 \\
\hline
\end{tabular}

19a. NAME OF RESPONSIBLE PERSON Noel Potts

19b. TELEPHONE NUMBER (include area code)

(217) 352-6511, X-7648

Standard Form 298 (Rev. 8-98)

Prescribed by ANSI Std. 239.18 